\title{
Geomorphic and stratigraphic evidence for an unusual tsunami or storm a few centuries ago at Anegada, British Virgin Islands
}

\author{
Brian F. Atwater - Uri S. ten Brink - Mark Buckley $\cdot$ Robert S. Halley \\ Bruce E. Jaffe • Alberto M. López-Venegas • Eduard G. Reinhardt • \\ Maritia P. Tuttle $\cdot$ Steve Watt $\cdot$ Yong Wei
}

Received: 1 February 2010/Accepted: 6 September 2010/Published online: 26 October 2010

(C) The Author(s) (outside the USA) 2010. This article is published with open access at Springerlink.com

\begin{abstract}
Waters from the Atlantic Ocean washed southward across parts of Anegada, east-northeast of Puerto Rico, during a singular event a few centuries ago. The overwash, after crossing a fringing coral reef and $1.5 \mathrm{~km}$ of shallow subtidal flats, cut dozens of breaches through sandy beach ridges, deposited a sheet of sand and shell capped with lime mud, and created inland fields of cobbles and boulders. Most of the breaches extend tens to hundreds of meters perpendicular to a 2-km stretch of Anegada's windward shore. Remnants of the breached ridges stand $3 \mathrm{~m}$ above modern sea level, and ridges seaward of the breaches rise 2.2-3.0 $\mathrm{m}$ high. The overwash probably exceeded those heights when cutting the breaches by overtopping and incision of the beach ridges. Much of the sand-and-shell sheet contains pink bioclastic sand that resembles, in grain size and composition, the sand of the breached ridges. This sand extends as much as $1.5 \mathrm{~km}$ to the south of the breached
\end{abstract}

This article is intended for tsunami-geology issue of Natural Hazards edited by Ioan Nistor: inistor@uottawa.ca.

Electronic supplementary material The online version of this article (doi:10.1007/s11069-010-9622-6) contains supplementary material, which is available to authorized users.

B. F. Atwater $(\bowtie)$

U.S. Geological Survey at University of Washington, Seattle, WA 98195-1310, USA

e-mail: atwater@usgs.gov

U. S. ten Brink

U.S. Geological Survey, 384 Woods Hole Road, Woods Hole, MA 02543-1598, USA

e-mail: utenbrink@usgs.gov

M. Buckley · B. E. Jaffe · S. Watt

U.S. Geological Survey, 400 Natural Bridges Drive, Santa Cruz, CA 95060, USA

e-mail: mbuckley@usgs.gov

B. E. Jaffe

e-mail: bjaffe@usgs.gov

S. Watt

e-mail: swatt@usgs.gov 
ridges. It tapers southward from a maximum thickness of $40 \mathrm{~cm}$, decreases in estimated mean grain size from medium sand to very fine sand, and contains mud laminae in the south. The sand-and-shell sheet also contains mollusks-cerithid gastropods and the bivalve Anomalocardia — and angular limestone granules and pebbles. The mollusk shells and the lime-mud cap were probably derived from a marine pond that occupied much of Anegada's interior at the time of overwash. The boulders and cobbles, nearly all composed of limestone, form fields that extend many tens of meters generally southward from limestone outcrops as much as $0.8 \mathrm{~km}$ from the nearest shore. Soon after the inferred overwash, the marine pond was replaced by hypersaline ponds that produce microbial mats and evaporite crusts. This environmental change, which has yet to be reversed, required restriction of a former inlet or inlets, the location of which was probably on the island's south (lee) side. The inferred overwash may have caused restriction directly by washing sand into former inlets, or indirectly by reducing the tidal prism or supplying sand to postoverwash currents and waves. The overwash happened after A.D. 1650 if coeval with radiocarbon-dated leaves in the mud cap, and it probably happened before human settlement in the last decades of the 1700s. A prior overwash event is implied by an inland set of breaches. Hypothetically, the overwash in 1650-1800 resulted from the Antilles tsunami of 1690, the transatlantic Lisbon tsunami of 1755 , a local tsunami not previously documented, or a storm whose effects exceeded those of Hurricane Donna, which was probably at category 3 as its eye passed $15 \mathrm{~km}$ to Anegada's south in 1960.

Keywords Tsunami $\cdot$ Stratigraphy $\cdot$ Caribbean

\section{Introduction}

Five papers in this volume deal with recently discovered evidence that seawater a few centuries ago washed over low parts of Anegada, an island $140 \mathrm{~km}$ ENE of Puerto Rico (Fig. 1). The papers share the challenge of distinguishing, in geologic records, between tsunamis and storms in a setting where grand examples of both can be expected. The papers have the further goal of clarifying the earthquake and tsunami potential of the

R. S. Halley

137652600 Road, Cedaredge, CO 81413, USA

e-mail: halleyrobert@earthlink.net

A. M. López-Venegas

\#723 Quintas de Santa María, Mayagüez, PR 00680, USA

e-mail: amlopex@gmail.com

E. G. Reinhardt

School of Geography and Earth Sciences, McMaster University, 1280 Main Street West, Hamilton, Ontario L8S 4K1, Canada

e-mail: ereinhar@mcmaster.ca

M. P. Tuttle

M. Tuttle \& Associates, HC 33 Box 48, Georgetown, ME 04548, USA

e-mail: mptuttle@earthlink.net

Y. Wei

NOAA/PMEL, 7600 Sand Point Way NE, Seattle, WA 98115, USA

e-mail: yong.wei@noaa.gov 

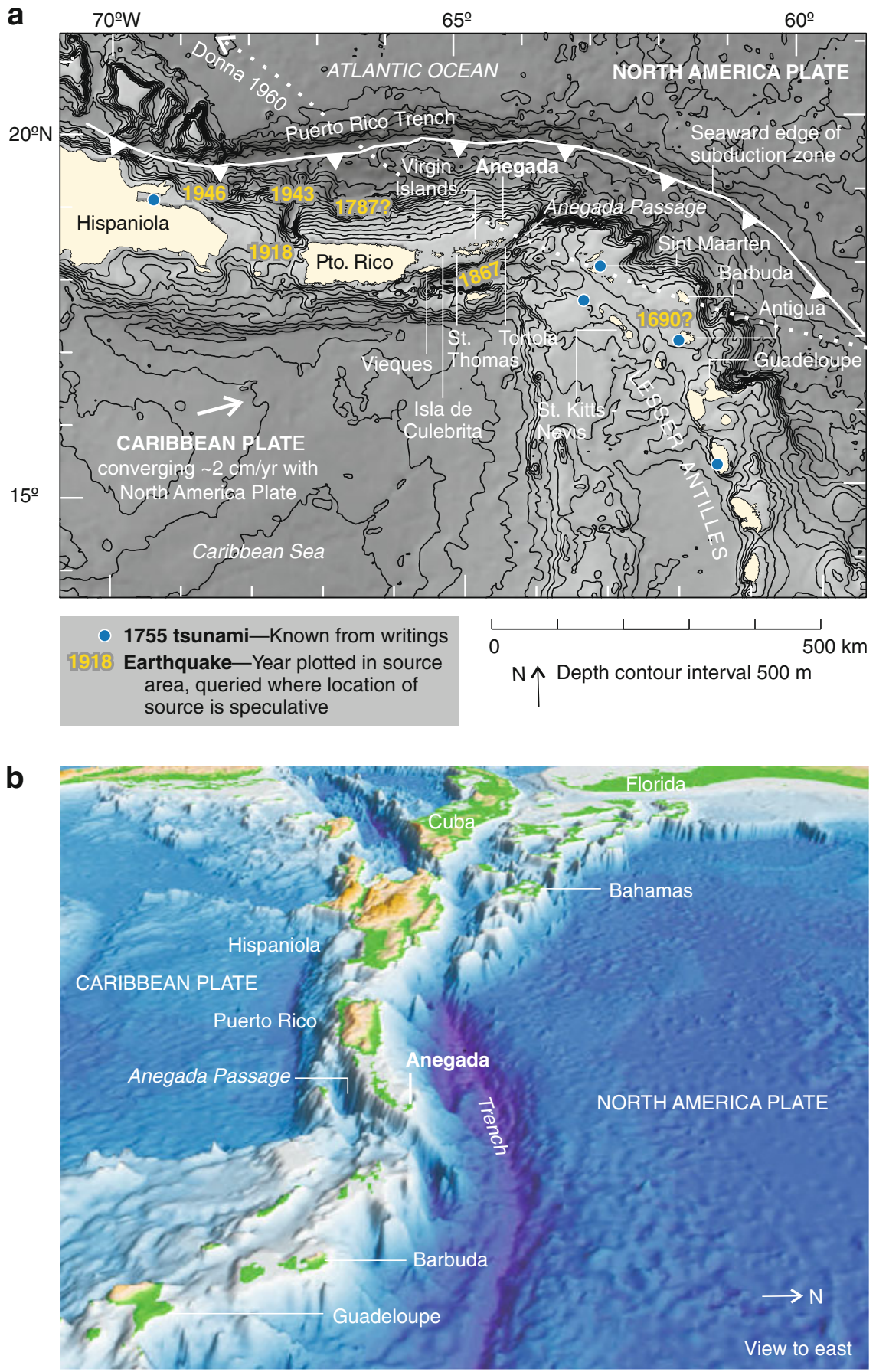

Fig. 1 Tectonic plates and physiography of the northeast Caribbean. a Plan view. Sources: plateconvergence direction and rate, López (2006); 1755 tsunami, O’Loughlin and Lander (2003); Hurricane Donna (Dunn 1961). b Oblique view westward 
subduction zone that conveys parts of the North America and South America Plates beneath the Caribbean Plate. Can this subduction zone, which slants beneath the Lesser Antilles and Puerto Rico, generate thrust earthquakes even though it has failed to do so in recent decades (Stein 1982)? If it does generate such earthquakes, can they attain moment magnitude 8 (McCann 1984; LaForge and McCann 2005) or 9 (Geist and Parsons 2009; McCaffrey 2008)? The answers bear on earthquake and tsunami hazards in the Caribbean (ten Brink et al. 1999; Mann 2005; Mercado-Irizarry and Liu 2006) and, farther afield, on tsunami hazards along the U.S. Atlantic coast (Geist and Parsons 2009; ten Brink 2009).

This Anegada paper sets the stage for its four companions. It introduces three kinds of evidence for overwash: breaches, a sheet of sand and shell, and fields of cobbles and boulders. We use stratigraphy, radiocarbon ages, and historical events to assign most of this evidence to the interval A.D. 1650-1800, and we conclude by ascribing the inferred overwash to a tsunami or to an unusual storm. The companion papers further assess these explanations by using mollusks and foraminifera to infer the provenance of the sand-andshell sheet (Reinhardt et al. 2010; Pilarczyk and Reinhardt 2010) and by using boulder size, spacing, and orientation in comparison with the bouldery deposits of modern tsunamis and storms (Watt et al. 2010; Buckley et al. 2010).

The paper digresses on a history of ponds that successively occupied the interior of Anegada. At the time of the inferred overwash, the island held a pond with salinities close to marine (marine pond, Sect. 6.1; Reinhardt et al. 2010). Soon after the inferred overwash, this pond was succeeded by smaller hypersaline ones, some of which are now isolated from the others at low water (salt ponds, Sect. 4.3). We delve into this history primarily because the change from marine to hypersaline serves much like a volcanic-ash layer in correlations among the various kinds of evidence for overwash. In addition, the salt ponds beneficially exclude crabs that would otherwise bioturbate the sand-and-shell sheet.

\section{Methods}

This paper is based on roughly 100-person days of field reconnaissance, partly in March 2008 and the rest a year later. Nearly all the work took place in the west-central part of Anegada, in the vicinity of Red Pond and Bumber Well Pond (Figs. 2a, 3a).

We studied the island's landforms by checking old reports and maps (ESMT 1; Fig. 2c, d), measuring heights by differential GPS (ESMF 1-2), and by using several sets of airphotos. The airphotos, courtesy of the Department of Disaster Management of the British Virgin Islands, include a set taken in 1945 that provides oblique views in black and white. A later black-and-white set, from 1969, provides vertical stereo coverage at 1:12,000 scale. We also used color vertical airphotos of 1:10,000 and 1:5,000 scales taken in 2002. Rectified versions of the photos from 2002 provided the base map on which we sketched the island's geology and plotted GPS-located sites (Figs. 2a, b, 5; ESMF 2).

To learn about the local effects of storms, we interviewed elders who witnessed Hurricane Donna at Anegada. They provided recollections of the storm surge and of sediment it did or did not carry. Their observations are restricted to The Settlement, in the southeastern part of the island (Fig. 2a; details in the electronic supplementary figure ESMF 1a-c).

Most of the stratigraphy was uncovered with shovels. We observed it mainly on the walls of hand-dug pits (examples, Fig. 4a-d; ESMF 3-7). We sampled some of the pit walls with plastic gutter $12 \mathrm{~cm}$ wide, and we extended some of the pits with gouge cores $2 \mathrm{~cm}$ in diameter. 
We measured elevations in 2008 by third-order leveling with closure errors of $0-3 \mathrm{~cm}$. This leveling provided vertical control for a stratigraphic cross-section through Bumber Well Pond and the inferred overwash deposits to its north (Figs. 5, 6, 7). We linked the leveling to tide levels measured on 23 March 2008 by means of a staff planted beside mangroves on the island's leeward shore. To put that day's tides in context of spring and neap cycles, we checked predictions for Tortola, $50 \mathrm{~km}$ to the southwest (http://www. pol.ac.uk/ntslf/pdf/Tortola_2008_+0400.pdf).

Differential GPS in 2009 provided extensive vertical control for beach ridges, boulders, and places reportedly flooded by the storm surge of Hurricane Donna in 1960 (ESMF 1, ESMF 2). Watt et al. (2010) describe how the DGPS data was collected and how it was referenced to an approximate mean sea level datum.

Most of our radiocarbon ages were measured on leaves, sticks, and mangrove roots, and on the shells of salt-water mollusks (Fig. 8, ESMT 2). To convert from radiocarbon years to sidereal years, we used version 5.01 of the calibration program Calib (http://calib.qub. ac.uk/calib/) along with the IntCal04 calibration data (Reimer et al. 2004) for the plant remains and the Marine04 calibration data (Hughen et al. 2004) for the molluskan shells.

We report the calibrated ages as ranges that nominally span two standard deviations. The ranges for the plant remains (plotted in black in Fig. 8b) probably approximate 95-percent confidence because their carbon came from the well-mixed atmospheric reservoir. For the shells, however, the reported ranges (plotted in blue) probably fall short of two standard deviations because of unknowns about carbon reservoirs and diagenetic changes.

The unpropagated carbon-reservoir uncertainties in the shell ages may amount to $100{ }^{14} \mathrm{C}$ year or more. Regionally, the age of modern, pre-bomb Caribbean surface water resembles the global average of about $400{ }^{14} \mathrm{C}$ year; its local reservoir corrections, $\Delta \mathrm{R}$, are within a few tens of radiocarbon years of zero (Reimer and Reimer 2001). We therefore assume $\Delta \mathrm{R}=0$. But this simplifying assumption neglects temporal variability in Caribbean surface water: at Puerto Rico its radiocarbon activity ranged from -59 to -43 parts per thousand (ppt) between 1750 and 1950, probably because of mixing of water masses (Kilbourne et al. 2007); and in Florida, the reservoir correction for parts of the middle Holocene is close to $300{ }^{14} \mathrm{C}$ year (Druffel et al. 2008). In a further carbon-reservoir uncertainty, the dated mollusks took up carbon not directly from the Caribbean but instead from a shallow bay (Sect. 6.1.1; Reinhardt et al. 2010) where winds are likely to have mixed in young carbon from the atmosphere and groundwater probably injected old carbon from Anegada's limestone.

\section{Setting}

\subsection{Tectonics}

Anegada is the island closest to the Puerto Rico Trench, an abyss that marks the seaward edge of the North America-Caribbean plate boundary north of Puerto Rico and the U.S. and British Virgin Islands (Fig. 1a). The interplate motion, averaging two meters per century, is nearly parallel to the trench (López 2006). GPS measurements from 1994 to 2005 provide evidence for negligible coupling between the plates north of Puerto Rico but roughly 50 percent coupling northeast and east of Anegada (Manaker 2008).

Anegada adjoins the edge of a submarine slope that descends nearly $8 \mathrm{~km}$ to the floor of the Puerto Rico Trench, $125 \mathrm{~km}$ to the north (ten Brink et al. 2004; Grindlay et al. 2005).

The island is perched near the eastern end of a submarine platform that flanks Puerto Rico and most of the Virgin Islands and terminates to the south at Anegada Passage (Fig. 1b). This 
platform was largely subaerial during glacial-age lowstands of the sea (Dunne and Brown 1979). North of Puerto Rico the platform is composed of Oligocene and Miocene carbonate strata that tilt toward the trench, perhaps in response to a tear in the subducting plate (ten Brink 2005) or in response to subduction erosion (Grindlay et al. 2005).

\subsection{Earthquakes and tsunamis}

To summarize first: Notable earthquakes in Anegada's vicinity occurred in 1690, 1785, 1787, 1843, and 1867. Tsunamis were associated with the 1690 and 1867 shocks, and both the 1755 and 1761 Lisbon tsunamis registered in the Caribbean.

The 1690 earthquake caused strong shaking to Anegada's east, at Antigua, St. Kitts, and Nevis, as did an earthquake in 1843 . The 1690 earthquake also caused a tsunami at Nevis and both shaking and tsunami to Anegada's south, in St. Thomas (Robson 1964; Bernard 1988; McCann et al. undated; Dorel 1981). It is not known whether the fault ruptures occurred at, above, or below the plate boundary (Stein 1982; McCann 1984).

The 1785 earthquake, likewise of undetermined source, struck Tortola, $50 \mathrm{~km}$ southwest of Anegada. It was also noted in Antigua and St. Kitts (Robson 1964; McCann et al. undated).

The 1787 earthquake has been ascribed to rupture of the plate-boundary off Puerto Rico's north shore (McCann 1984; LaForge and McCann 2005; McCann 1985). However, Spanish language records spell out damage from the earthquake on the north coast of Puerto Rico without telling of any accompanying tsunami (McCann et al. undated), and catalogs contain no reports of correlative damage of any kind on islands to the east (Robson 1964; Shepherd and Lynch 1992).

A large earthquake in 1867 spawned a tsunami in the Virgin Islands, Puerto Rico, and the Lesser Antilles. The fault rupture was likely located in Anegada Passage (Reid and Taber 1920; Zahibo 2003). The tsunami would have reached the British Virgin Islands from the south. There, on the south side of Tortola, the tsunami height was about $1.5 \mathrm{~m}$ in Tortola (O'Loughlin and Lander 2003). We have not seen a report of its effects farther north at Anegada.

The 1755 Lisbon tsunami reached estimated heights of 2-6 m east of Anegada and registered to Anegada's west in Hispaniola and Cuba (O'Loughlin and Lander 2003) (Fig. 1a, blue dots). It was not noticed along the U.S. Atlantic seaboard (Barkan et al. 2009). The tsunami's source is poorly understood (Baptista and Miranda 2009). The parent earthquake, which may have attained magnitude 9 , hypothetically resulted from a rupture $600 \mathrm{~km}$ long on a fault trending NNW-SSE (Muir-Wood and Mignan 2009). Marine geophysical surveys of the tsunami's source region instead show reverse faults trending NE-SW and strike-slip faults trending WNW-ESE (Zitellini et al. 2009). The 1761 Lisbon tsunami is also known from the Caribbean, though from Barbados only (Baptista et al. 2006).

\subsection{Hurricanes}

Hurricanes spawned in the tropical Atlantic Ocean off Africa commonly run westward through the northeast Caribbean Sea. The most disastrous hurricane in the Caribbean's written history occurred in 1780. It passed to the south of St. Kitts on October 13 and curled northward around the west end of Puerto Rico two days later (Millás and Pardue 1968). Closer to Anegada, an early hurricane in the written history of Tortola occurred in 1713 (Pickering 1983). A particularly damaging one struck there in 1819 (ESMT 1) and was said to have closed an inlet at Anegada (Sect. 6.3, below). 
The largest hurricane at Anegada in the last 50 years or more, Hurricane Donna, occurred in 1960. As it crossed Sint Maarten (location, Fig. 1a), Donna's maximum sustained wind reached 110 knots (about $55 \mathrm{~m} / \mathrm{sec}$ ), and the barometric pressure was measured at $952 \mathrm{mb}$ - category 3 on the Saffir-Simpson scale (Dunn 1961). It probably remained at category 3 until it approached Florida. The storm's eye passed about $15 \mathrm{~km}$ south of Anegada. Several elders, interviewed separately in 2008, described Donna's storm surge as slow-moving but brief. They observed the storm surge, though only in the island's sole village at the time-The Settlement, near Anegada's south shore (Fig. 2a, c). The flooding there extended $0.5 \mathrm{~km}$ inland, reached heights close to $2.5 \mathrm{~m}$ above mean sea level, but happened gradually enough to produce little sedimentary record (ESMF 1a-c).

Hurricanes stronger than category 3 are likely to have hit Anegada. For Vieques, $150 \mathrm{~km}$ to the west-southwest, statistics on synthetic storms give an average recurrence interval of about 50 years for maximum surface winds of 110 knots and 200 years for 130 knots (Woodruff et al. 2008a). The latter corresponds to category 4. For the vicinity of Anegada itself, simulation of a 100-year storm give wind speeds of 110 knots (Caribbean Disaster Mitigation Project 2002). This simulation also gives storm-surge heights of $2 \frac{1}{2} \mathrm{~m}$ on Anegada's south shore but about $3 / 4 \mathrm{~m}$ on the north shore. Broad shelves tend to yield greater storm surges than narrow shelves (Coch 1994), a difference that probably explains this contrast in surge height (Fig. 1).

Hurricane histories before Columbus have been inferred from sand layers at two sites about $100 \mathrm{~km}$ southwest of Anegada. At one of these site, a lagoon facing the Caribbean Sea on the south side of Vieques (Woodruff et al. 2008b), sand layers provide evidence for barrier overwash by hurricane waves of the last 1,500 years (Woodruff et al. 2008a). Five of the inferred hurricanes probably date between A.D. 1700 and 1850 (Woodruff et al. 2008b; Mann et al. 2009). At the other site, a salt pond on Isla de Culebrita, overwash from the Atlantic Ocean has deposited sand layers $1 \mathrm{~cm}$ thick ascribed to hurricanes of the last 2,000 years (Donnelly 2005). Also found at this site is an anomalous sand layer $20 \mathrm{~cm}$ thick probably less than 750 years old.

\section{Sedimentary environments and landforms}

Anegada, covering $54 \mathrm{~km}^{2}$, extends $17 \mathrm{~km}$ along a west to southeast arc (Dunne and Brown 1979). It is flanked to its windward (north and northeast) side by a fringing reef that continues another $15 \mathrm{~km}$ to the southeast. Patch reefs dot the area offshore in the island's lee (Fig. 2c).

The island is nearly flat. It consists mostly of limestone, probably Pleistocene in age (Howard 1970; Horsfield 1975), that crops out mainly in the east and rises no more than $8 \mathrm{~m}$ above sea level (Fig. 2a). The limestone extends westward beneath the deposits Holocene beaches and ponds. Here we sketch the island's nearshore and onshore environments here (Sects. 4.1, 4.2, 4.3) to provide local context for the overwash evidence to follow (Sects. 5, 6, 7 and companion papers).

\subsection{Fringing reef and reef flat}

The reef north of Anegada rises southward from spurs and grooves to a crest at low-tide level (Fig. 3a-c). When surveyed in the 1970s, before Caribbean coral populations collapsed (Gardner et al. 2003), the reef's framework taxa included the boulder coral 


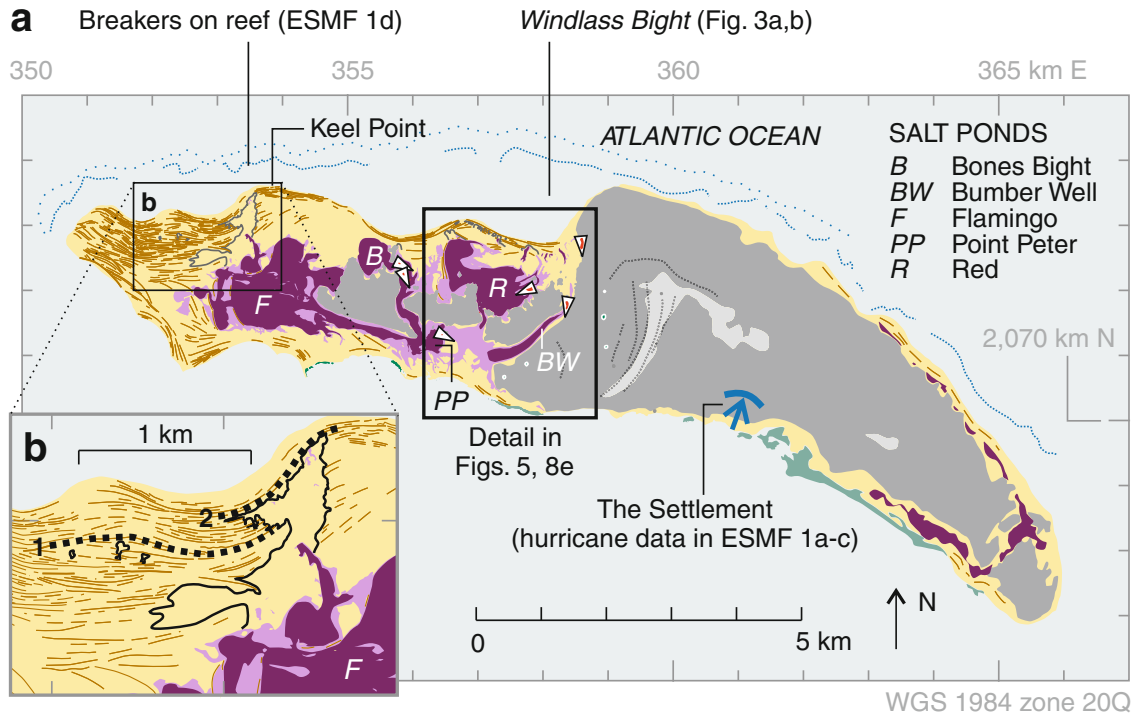

MAP UNITS

Mangrove (modern) - Swamps on leeward (south) shore Unconsolidated deposits (Holocene)

Sand-Above seasonal high water of salt ponds. Deposited mainly on prograding beaches and their back-beach dunes

Muddy sand-Bioturbated by fiddler crabs. Mud derived from seasonal flooding by salt ponds. Upper limit mapped at lowest widespread shrubs or trees

Microbial mats and evaporite crusts-Deposited on perennial floors of salt ponds.

Boulders and cobbles-Fields appended to limestone outcrops. Red symbol shows extent. White triangle shows approximate flow direction inferred from the field's elongation and probable source.

Limestone (Neogene, probably Pleistocene)-Described by Howard (1970, p. 7) as rudaceous biocalcarenite to arenaceous calcilutite. Contains fossil coral and whelk; the coral taxa include Diploria, Montastrea, Acropora, and Millepora.

\section{OTHER SYMBOLS}

Storm surge of Hurricane Donna (1960)-Reportedly entered from the south after passage of the hurricane's eye. Blue symbol shows generalized limit in The Settlement inferred from eyewitness accounts (ESMF 1a-c).

Fringing coral reef (modern) — Sketched from airphotos taken in 2002

Seaward limit-Northern edge of spur-and-groove bathymetry (example, Fig. 3c)

Crest-Marked by breaking waves (Fig. 3c)

Beach ridge crest (Holocene) - Line dashed where ridge is indistinct or approximately located on airphotos from 2002. Line thick where ridge cuts across trend of several earlier ridges.

Margin of breach-Mapped where cuts across beach ridge or ridges. In many cases, partly encloses a small salt pond (Fig. 3c) or salt flat. Margin may be depositional on windward (north) side tangent to a beach ridge.

Inferred shoreline at time of breach-Shown only on inset map. 1, older; 2, younger

Limestone landforms

Sinkhole (Holocene and Pleistocene)-Map shows only those confirmed in field.

Lineament (Neogene)-Roughly north-south lines may represent bedding or sedimentary facies. Roughly east-west line to their north coincides with a topographic step that may represent a Pleistocene shoreline.

Highest parts of island-About 7-8 $\mathrm{m}$ above modern sea level. Data from Shuttle Radar Topographic Mission, 90-m horizontal resolution

Fig. 2 Maps of Anegada. a Geologic sketch map of Anegada. Field checked mainly in area of Fig. 5. b Expanded view of beach ridges and breaches near Keel Point. c, d Map surveyed in 1831 by Schomburgk (1832) 

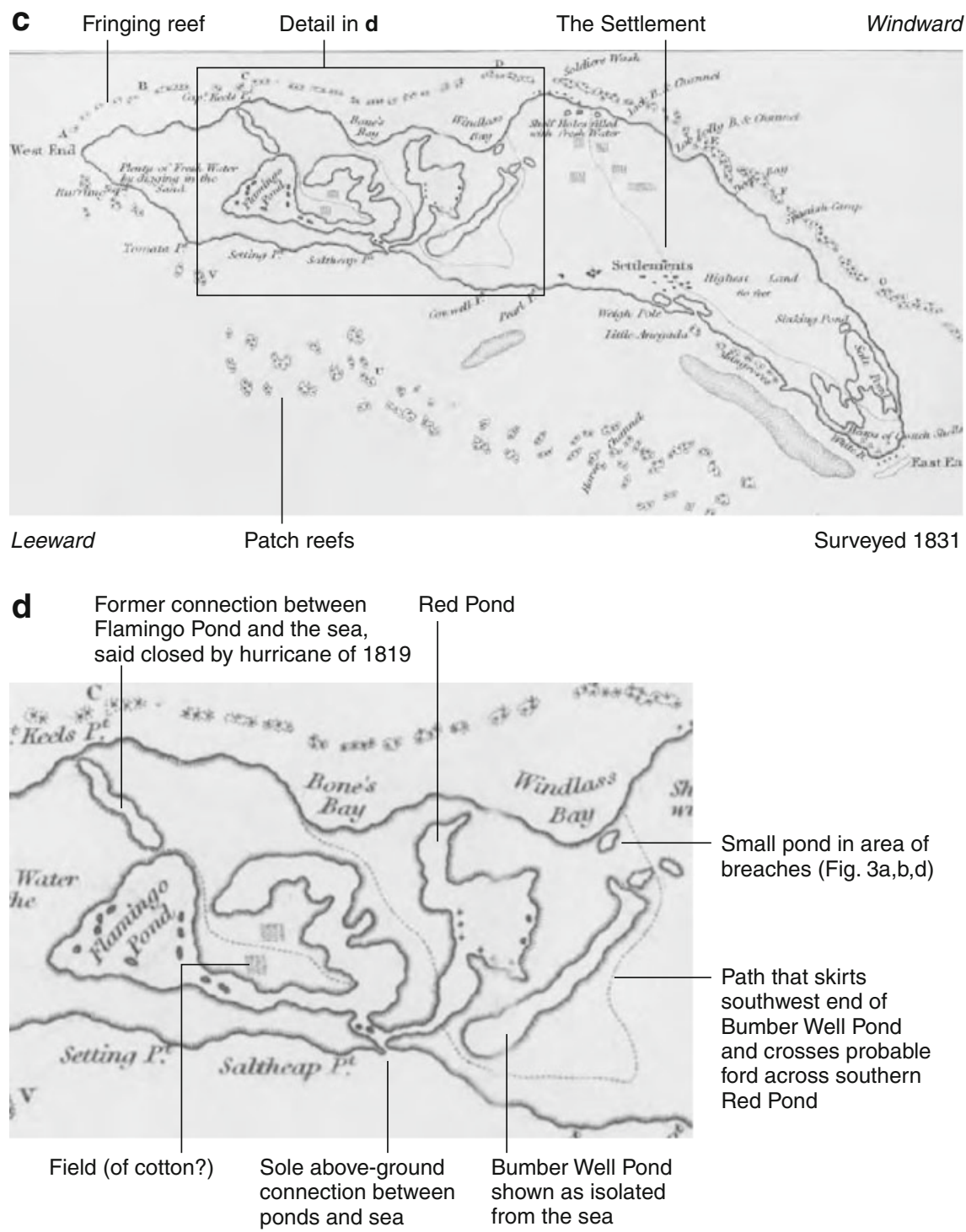

Fig. 2 continued

Montastrea annularis, the elkhorn coral Acropora palmata, and the brain coral Diploria (Dunne and Brown 1979).

This fringing reef shelters Anegada's north shore from storm waves. In March 2008, while some of us were doing field work at Anegada, a stationary low-pressure system over the North Atlantic generated swell with open-sea heights of $5 \mathrm{~m}$ or more that attacked the northeast Caribbean (Lefèvre 2009). At Anegada, the swell produced thundering breakers on the fringing reef while yielding waves a few tens of centimeters high at the beach (ESMF 1d). The event did cause localized retreat of the north shore itself but failed to overtop its beach ridges. 
Fig. 3 Beach ridges and beach deposits on the north side of Anegada. a-f Aerial views of Windlass Bight and vicinity. a Oblique view from north. b Coral reef, shallow flat behind reef, and beach ridges. c, d Closeups of reef and ridges, respectively. e, f Stero pair of beach ridges cut by transverse swales. $\mathbf{g}$ Notch beside northeast Red Pond (location, Fig. 5). Stripes on shovel handle are $10 \mathrm{~cm}$ long. $\mathbf{h}$, $\mathbf{i}$ The encrusting pink foraminfera Homotrema rubrum on a washed-up piece of a branched coral and as grains in beach sand at Keel Point

Between the reef and the north shore is a sandy subtidal flat that extends $50-1,500 \mathrm{~m}$ perpendicular to shore (example, Fig. 2b). It has been called a lagoon but is fully open to the sea (Dunne and Brown 1979). The flat's depth at low tide is less than $2 \mathrm{~m}$ in southern Windlass Bight (location, Fig. 3a, b), where we stood on it, and as much as $4 \mathrm{~m}$ along profiles surveyed by Dunne and coworkers farther east. Its biota, in the 1970s, included the conch Strombus gigas on a sandy bottom dotted by the seagrasses Thalassia and Halodule, at a depth of 2-3 m (Dunne and Brown 1979).

The coral taxa that used to dominate the modern island's reefs also abound in Anegada's pre-Holocene limestone (Dunne and Brown 1979; Howard 1970). A 19th-century explorer and naturalist, R.H. Schomburgk, said the limestone had been built by "the industrious tribe of lithophyta" (Schomburgk 1832).

\subsection{Beaches and beach ridges}

Corals also helped build the sandy western third of Anegada. This area consists of beach ridges (examples, Fig. 3a, d-f) that extend the island $3 \mathrm{~km}$ westward of its westernmost limestone outcrops (Fig. 2a). The beach sand has no evident sources other than the coral reefs off Anegada's shores and the coral-rich limestone on the island itself.

Most of the beach ridges of western Anegada crest a few meters above sea level. The ridges are taller along the island's windward (north) shore than along its leeward (south) shore. They were likely accreted by waves and currents driven westward by the prevailing trade winds and augmented from deposition of wind-blown sand. Differential GPS measurements show that those facing Windlass Bight, on the island's north shore, are typically in the range 2-4 $\mathrm{m}$ above mean sea level (ESMF 2).

The ridges probably formed with relative sea level similar to today's. Regionally, relative sea level has been rising about a meter per millennium in the last few thousand years (Toscano and Macintyre 2003). At Anegada, a shoreline notch suggests a Holocene relative sea-level maximum within today's intertidal range. We found this notch, and no higher one, on limestone shores of Red Pond (Fig. 3g) about a tenth of a meter above this hypersaline pond's low-water level. That elevation puts the notch in the middle of the oceanic intertidal zone (Sect. 4.3.1). The notch probably formed while the site of Red Pond was more open to the sea than it is today-when it was part of a larger marine pond that persisted until the overwash of AD 1650-1800 (Sect. 6.1.1).

Beach ridges southwest of Keel Point and beside Windlass Bight are abundantly cut by breaches (Fig. 2a, b). Many of the breaches are marked by unvegetated flats, some of which hold perennial salt ponds (Fig. 3a, d-f; ESMF 6). Below we interpret the breaches as evidence for catastrophic overwash (Sect. 5.1).

The beach deposits on Anegada's north shore are composed of bioclastic sand probably derived, for the most part, from the fringing reef. Classified in the field, the sand ranges from coarse sand where the lagoon's modest waves break, to fine sand at the highest wrack. The grains include reddish pieces of the foraminifera Homotrema rubrum (Fig. 3g, h). In Bermuda such grains are derived from tests millimeters in diameter that encrust the 

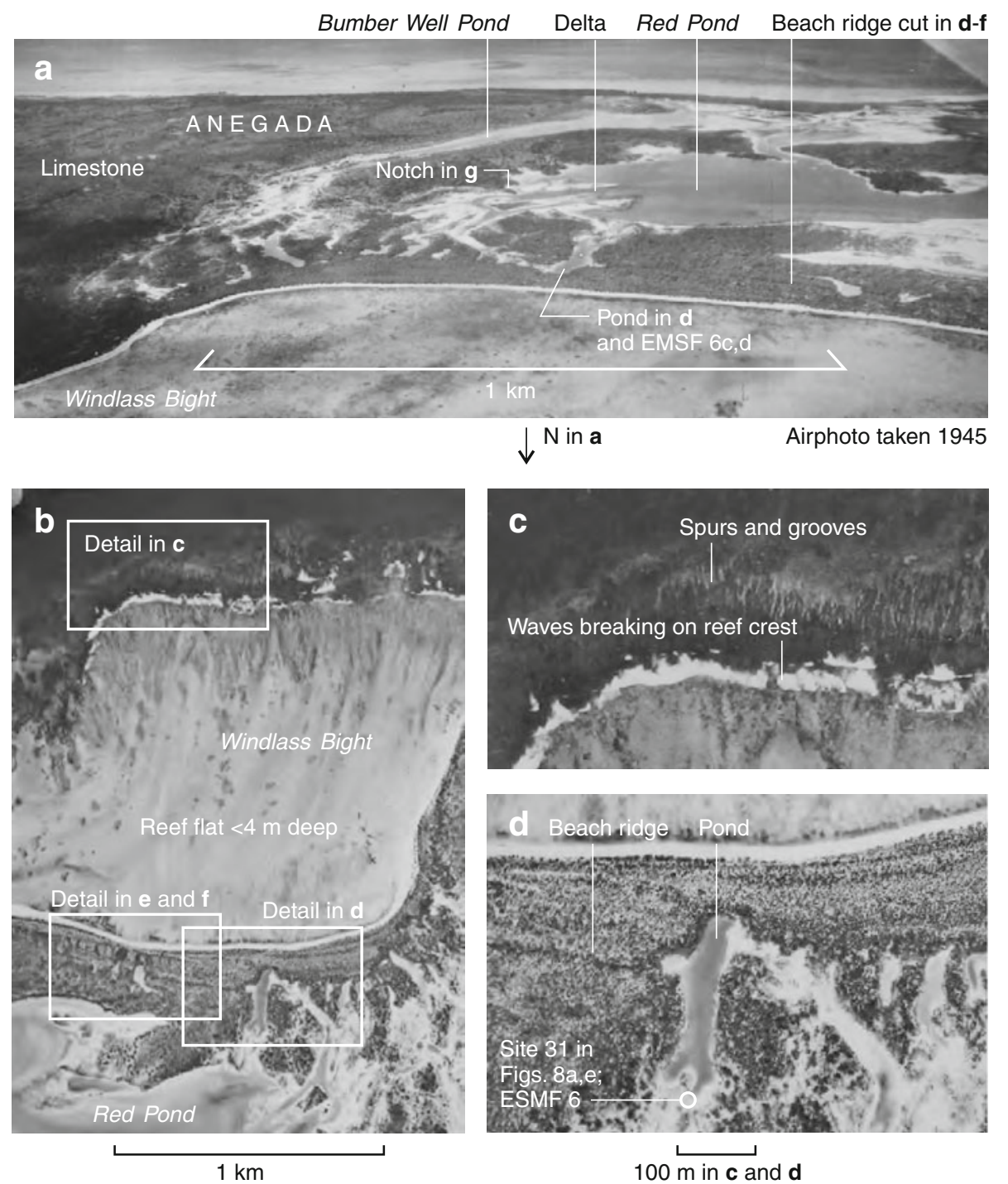

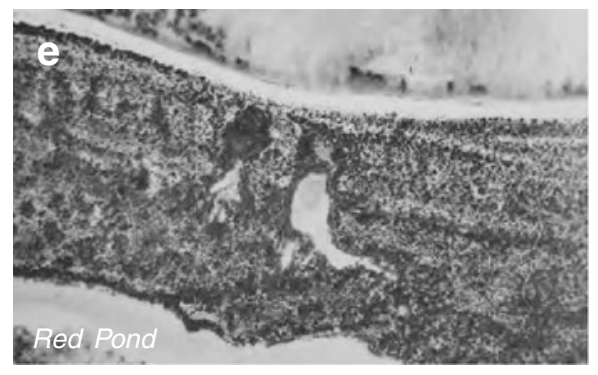

$100 \mathrm{~m}$ in e and $\mathbf{f}$

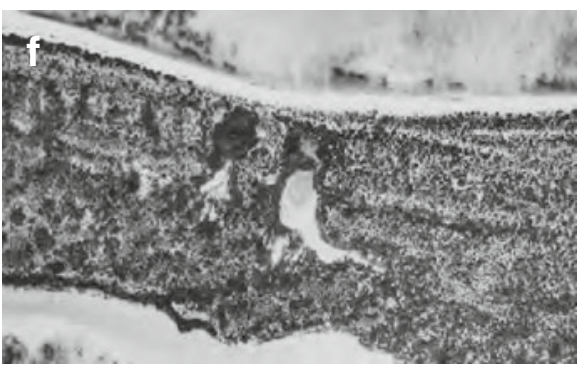

$\uparrow_{N \text { in b-f }}$

Airphotos in b-f taken 1969 

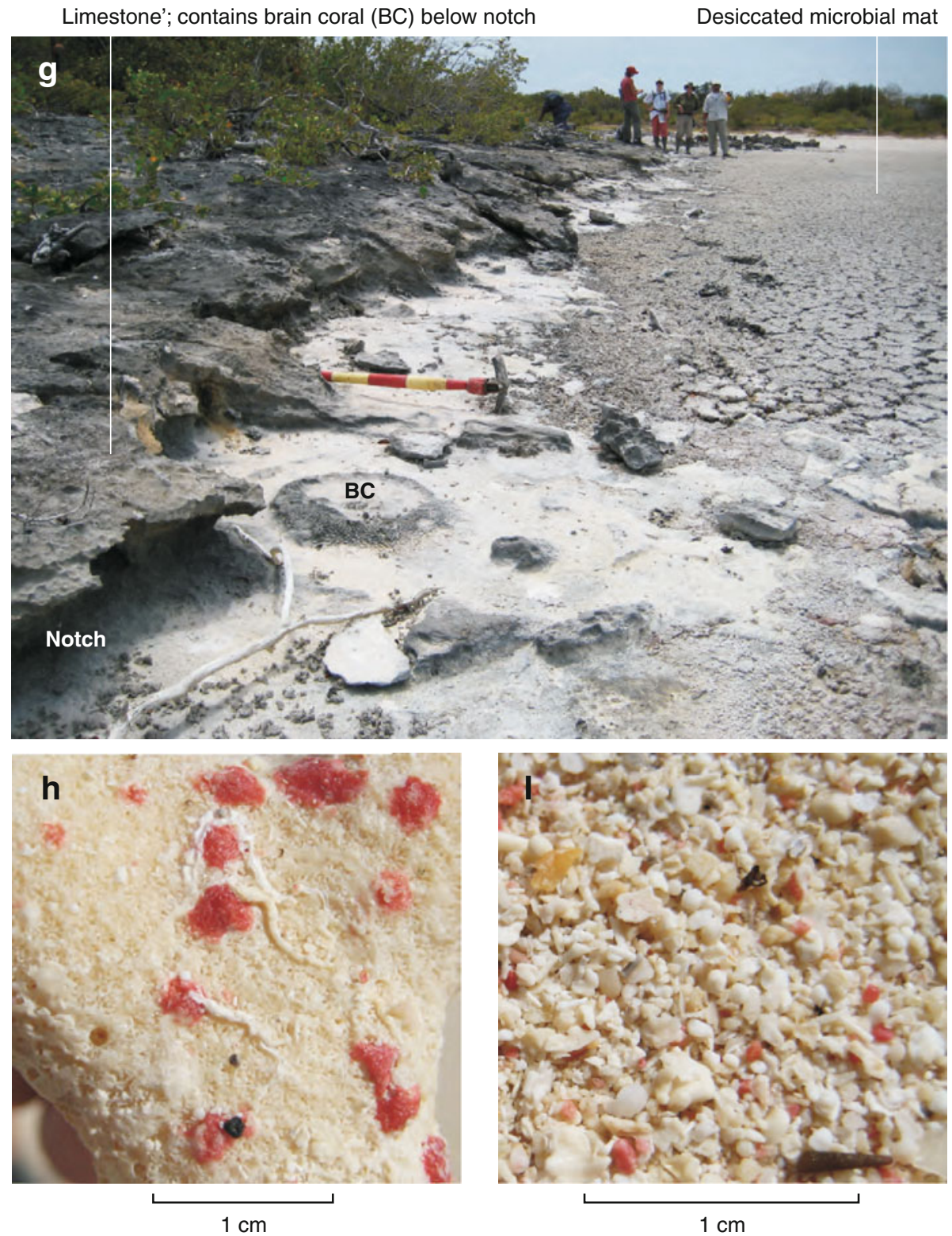

Fig. 3 continued

undersides of shells, corals, and detritus (Mackenzie 1965). They serve at Anegada as tracers of stratigraphic evidence for overwash (Sect. 5.2; Pilarczyk and Reinhardt 2010).

\subsection{Salt ponds}

The hypersaline waters of Flamingo, Bones Bight, Point Peter, Red, and Bumber Well Ponds cover much of western Anegada. These ponds are bounded in part by limestone 

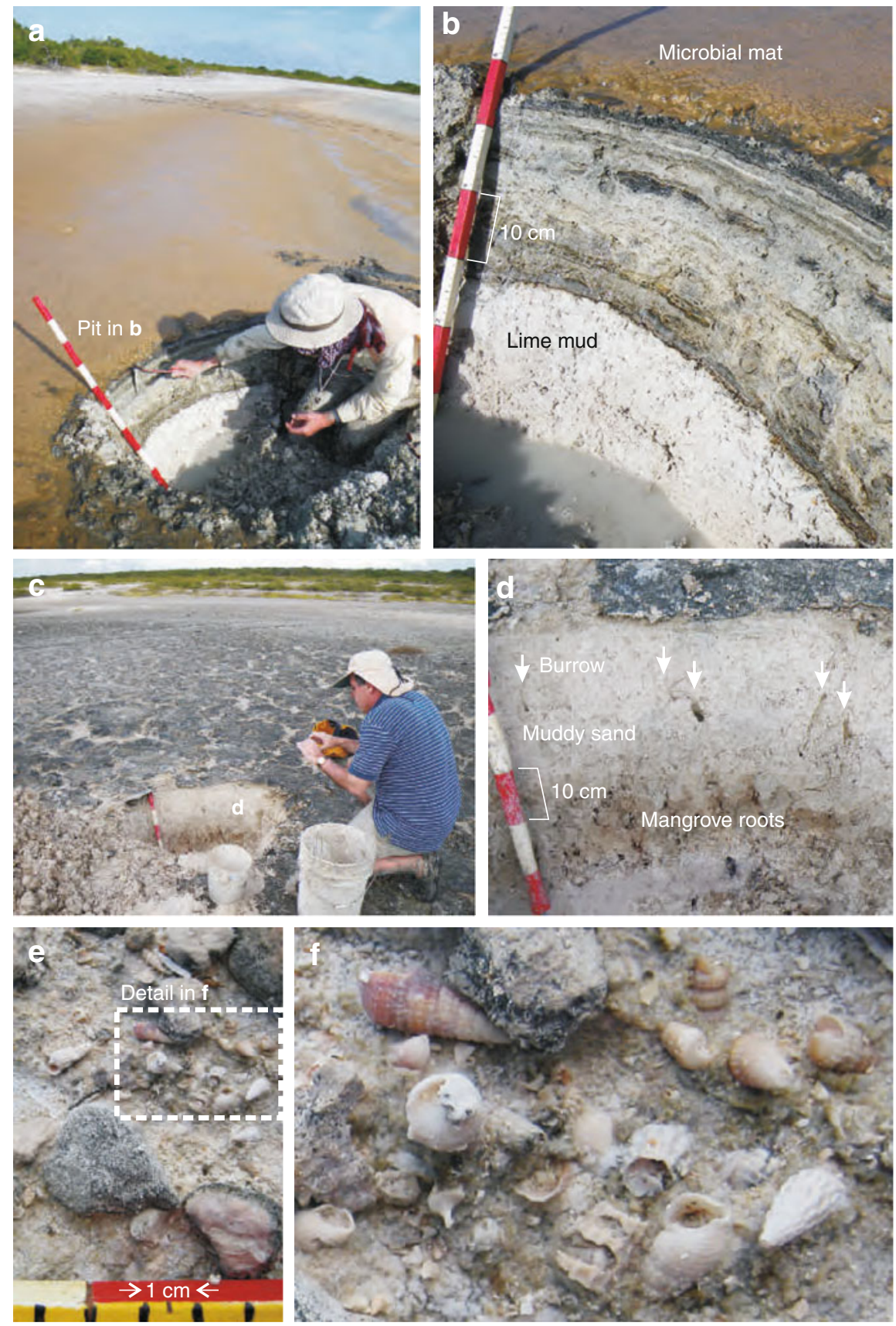

Fig. 4 Deposits on fringes of Anegada salt ponds. Locations, Fig. 5. a, b Wet microbial mat a day or two after its exposure by slight lowering of the level of Red Pond. No crabs or mangroves have disturbed the underlying stromatolitic laminae or their sharp contact with lime mud. c, d Muddy fine sand riddled with fiddler-crab burrows beneath a thin, dry, seasonal microbial mat north of Bumber Well Pond. e, f Etched shells of cerithid gastropods, relicts of a marine pond, litter a rocky flat near the south end of Bumber Well Pond 
uplands, and all but Point Peter also adjoin beach ridges of the north shore (Fig. 2a). Sandy flats on the southern part of the island separate the perennial parts of Red and Bumber Well Ponds from the other ponds and from one another (Fig. 5).

The hydrology and biology of Flamingo, Bones Bight, Point Peter, and Red Ponds received detailed study in the middle 1990s by Lianna Jarecki. The following summaries are based mainly on her findings (Jarecki 2003; Jarecki and Walkey 2006; Jarecki et al. 2006). We emphasize Red and Bumber Well Ponds because they and their surroundings provide the stratigraphic evidence for overwash described in Sect. 5.2.

\subsubsection{Salinity and isolation from the sea}

Evaporation in excess of precipitation and inflow produces salinities far greater than that of seawater at Flamingo, Bones Bight, Point Peter, and Red Ponds (Jarecki and Walkey 2006). The dissolved salts, measured monthly in 1995, averaged 93-184 ppt and, for Red Pond, reached $250 \mathrm{ppt}$ during the winter and spring dry season.

Seasonal precipitation reduces salinity while raising the ponds' water levels. Red Pond's levels in 1995 had a measured range of $20 \mathrm{~cm}$. They crested in autumn, during hurricane season, and bottomed out as salinity peaked in April and May. The seasonal high-water levels are marked, on airphotos and on the ground, by bathtub rings of angular limestone pebbles beside Bumber Well Pond, and by beach ridges on the west and north sides of Red Pond.

Pond levels scarcely vary with tidal fluctuations in the surrounding sea. The ocean tides rise and fall tens of centimeters daily; the maximum astronomical range is $40 \mathrm{~cm}$ at the nearest tide station, on Tortola (http://www.pol.ac.uk/ntslf/pdf/Tortola_2008_+0400.pdf). By contrast, daily fluctuations within the ponds, measured in 1995, amounted to $3.5 \mathrm{~cm}$ at Bones Bight Pond, $0.9 \mathrm{~cm}$ at Flamingo Pond, $0.8 \mathrm{~cm}$ at Point Peter Pond, and $1.9 \mathrm{~cm}$ at Red Pond (Jarecki and Walkey 2006).

Perennial connection to the sea through Anegada's leeward side produces little tidal flushing of Flamingo, Bones Bight, and Point Peter Ponds. The connecting channel, labeled at lower left in Fig. 5, is probably open year-around but constricts inland to a few meters in width and a few tens of centimeters in depth (Jarecki and Walkey 2006).

Red and Bumber Well Ponds stood below mean sea level when they were completely isolated from this channel in March 2008 and March 2009. They were less than $10 \mathrm{~cm}$ above low tide level on Anegada's leeward shore on a day (23 March 2008) when the tide range measured there was $44 \mathrm{~cm}$ (that day's predicted range at Tortola was $21 \mathrm{~cm}$ ).

Precipitates further attest to hypersaline conditions at Anegada. Gypsum encrusts the bottoms of Flamingo and Red Ponds (Jarecki and Walkey 2006). Several mounds of salt were harvested from ponds near the island's east end before 1970 (Howard 1970).

\subsubsection{Mats and crabs}

Most of the stratigraphic evidence for overwash is preserved beneath the microbial mats of perennial salt ponds and their seasonally flooded margins. The mat peat, horizontally laminated, forms part or all of a surficial unit that rests abruptly on other kinds of deposits (Fig. 4a, b). It tapers landward to a polygonally cracked veneer on areas of seasonal flooding (Fig. 4c, d).

The mats range from very soft to leathery. Their colors include reddish brown, purple, green, and black. They are dominated by cyanobacteria and diatoms in surface layers and purple sulfur bacteria at depth (Jarecki et al. 2006). 
Fiddler crabs, Uca burgersi, burrow into muddy sand on the ponds' seasonally flooded fringes (Fig. 5). On shores of Red Pond in 1995, monthly counts of the number of Uca burrows per square meter averaged 26 across 11 months and peaked in April at 200 (Jarecki 2003). Burrowing by fiddler crabs has destroyed much of Anegada's stratigraphic evidence for overwash outside the areas perennially covered by salt ponds.

\subsubsection{Mollusks}

Margins of western Anegada's salt ponds abound in dead mollusks. Jarecki (2003) noted that "one bivalve (Anomalocardia brasiliana) and 2 gastropods (Batillaria minima and Cerithium lutosum) were so common at the Anegada ponds and particularly at [Red and Flamingo Ponds] that their dead shells formed a pavement along some parts of the shorelines." She also noted shells of another gastropod, Cerithidea costada.

The dead assemblage extends into shrubby land above the seasonal high-water marks of Red and Bumber Well Ponds. As in the example in Fig. 4f, many of the shells are broken and pitted. Wind locally piles them against shrubs.

Below we interpret the shells as relicts of a bay that received far more inflow from the sea than do today's salt ponds. We further infer that soon after the inferred overwash, this marine pond lost most of its connection to the sea and consequently shrank into multiple salt ponds (Sect. 6.1).

\section{Evidence for overwash}

Anegada displays three kinds of evidence for overwash: dozens of breaches on the island's north side (examples in Fig. 3a, b, d-f); a clastic-sediment sheet dominated by sand and shell that extends at least $1.5 \mathrm{~km}$ inland (Fig. 6; ESMF 3-5); and fields of limestone boulders and cobbles that sole within that sheet (Fig. 7). All three are best explained, for the most part, by overwash from the north.

\subsection{Breaches}

Anegada's north shore is laced with swales that trend perpendicular to the modern shore and the beach ridges behind it (Fig. 3a-f, ESMF 2). Most or all of them probably resulted from incision during overwash of a beach-ridge plain 2-3 $\mathrm{m}$ above present sea level, heights inferred from measurements in ESMF 2. For brevity we therefore refer to them as breaches, with the caveat that some might have originated as tidal inlets (Sect. 5.1.2).

\subsubsection{Description of examples beside Windlass Bight}

Dozens of breaches extend roughly perpendicular to Anegada's north shore at Windlass Bight. Some are evident from their unvegetated surfaces tens of meters wide and as much as several hundreds of meters long (aerial overviews, Fig. 3a, b); and some of these contain perennial salt ponds. Others are smaller and are covered by mangroves (dark vegetation in stereo pair, Fig. 3e, f).

The breaches cut across sand, more obviously in the west than in the east. The western breaches, mostly small, cut across beach ridges (Fig. 3e, f). The eastern breaches are also flanked by sand (confirmed by pits and auger borings at yellow dots, Fig. 5) but this sand lacks preserved beach-ridge landforms (Fig. 4b, d; ESMF 2c). 


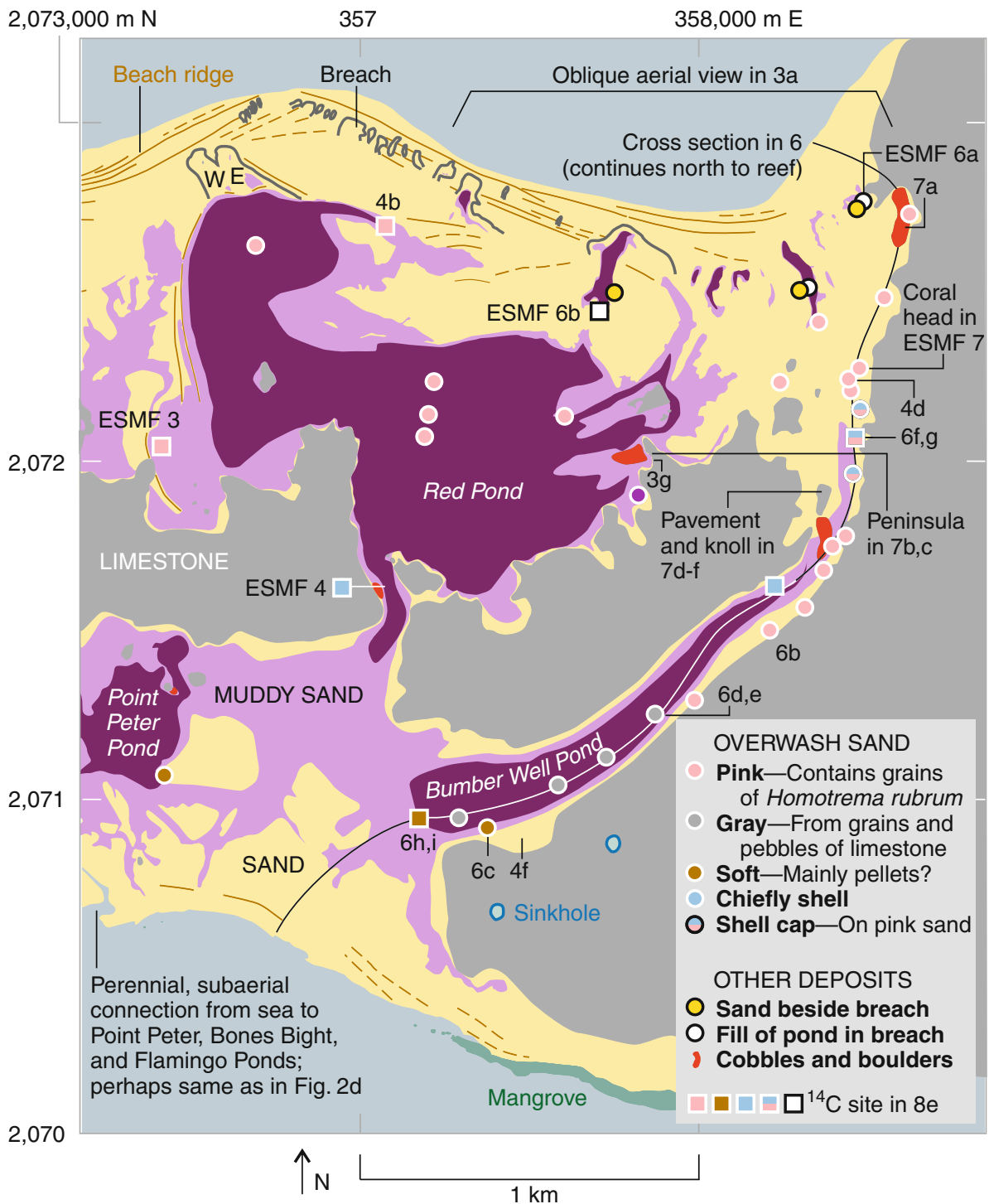

Fig. 5 Index map for overwash evidence at Red Pond, Bumber Well Pond, and vicinity. See Fig. 2a for island-wide context and an expanded explanation for map units and symbols. Plain number-letter labels locate photo sites by figure number; for instance, $4 \mathrm{~d}$ denotes Fig. $4 \mathrm{~d}$

Most of the breaches dissipate away from Windlass Bight, both by tapering of their unvegetated flats, as in the tadpole tail of the largest breach in Fig. 3e, f, and by shoaling southward from closed depressions. The floor of the large pond in Fig. 3d rises southward to a sandy divide that separates it from Red Pond (ESMF 6c,d). Only one of the breaches continues southward into a main salt pond: the curving channel that divides into deltaic distributaries at Red Pond (Fig. 3a, d).

A pair of breaches northwest of Red Pond each contains a closed depression, perhaps a plunge pool, in its upper reach (profiles D-D' and E-E' in ESMF 2a). The eastern 
Fig. 6 Overwash deposits and their bounding beds. Locations in map view, Fig. 5. Unlabeled scale bar in $\mathbf{b}-\mathbf{d}, \mathbf{f}$, and $\mathbf{h}$ denotes sand-and-shell sheet. a Generalized north-south cross-section showing distribution of facies along and beside the cross-section line. b Pink sand east of Bumber Well Pond. $\mathbf{c}$ Soft sand near south end of Bumber Well Pond. d, e Pebbly shelly sand beneath Bumber Well Pond. The material in e is a coarse fraction caught in a sieve with openings $1 \mathrm{~cm}$ across. f, $\mathbf{g}$ Pink sand north of Bumber Well Pond, capped by shell hash in $\mathbf{f}$. h, i Shelly soft sand at southwest end of Bumber Well Pond

depression (E in Fig. 5) holds a seasonal salt pond fringed with mangroves, while the western one $(\mathrm{W})$ reaches limestone bedrock. Both depressions extend below mean sea level. Southeastward from each of them the breach thalweg rises a meter or so, across tens of meters of sandy ground, before descending gradually toward salt flats that a Red Pond beach ridge impounds.

\subsubsection{Estimated threshold height for breaching beach ridges at Windlass Bight}

How high did water need to rise to cut the breaches by overtopping low places along beach ridge crests and cutting down through these parts of the ridges? We estimated this threshold height for breaching by using differential GPS measurements both along and across the crests of beach ridges. We measured remnants of one ridge that was breached. We also measured sections of several later beach ridges that sealed off the breaches. If these ridges formed under conditions similar to those that prevailed before the breaching, their heights provide an independent check on the heights of the breached remnants.

We infer that for minimum flow depths of $1 \mathrm{~m}$, the water that cut the breaches reached or exceeded a threshold height of $3 \mathrm{~m}$. All the beach-ridge crests, pre- and post-breaching, yielded heights 2-3 m above today's mean sea level (ESMF 2). They lack depositional gaps where we made topographic profiles along the crests (profiles I-I' of the breached ridge in ESMF $2 \mathrm{~b}$, and $\mathrm{N}-\mathrm{N}^{\prime}$ of an unbreached ridge in ESMF 2c).

The threshold height may have been lowest in the east, where the crest heights on profile $\mathrm{N}-\mathrm{N}^{\prime}$ descend to $2.2 \mathrm{~m}$ above sea level. By geomorphic superposition, this low ridge was built after the erosion that is marked by numerous elongate salt ponds and salt flats and by an absence of remnant ridges between them. By contrast, where crest heights are about $3.0 \mathrm{~m}$ on breached and unbreached ridges, remnant ridges remain distinctly preserved between breaches (ESMF 2b).

\subsubsection{Alternatives to breaching beside Windlass Bight}

It is possible that one or more of the breaches at Windlass Bight was already open, as a tidal inlet, at the time of overwash. Such immediately pre-overwash inlets are difficult to rule out in the east where breached ridges can be inferred solely from deposits (yellow dots, Fig. 5). The strongest candidate looks like a channel; it continues and divides southward into the delta of northeasternmost Red Pond. Immediately pre-overwash inlets are needed to explain how, until the time of overwash, the western interior of Anegada held a marine pond in which high salinity did not exclude cerithids or Anomalocardia (Sect. 6.1; Reinhardt et al. 2010).

In three respects, however, immediately pre-overwash inlets at Windlass Bight are neither necessary nor probable: (1) They are not necessary to help explain the breaches because overtopping and incision provide sufficient cause. The channel-like breach that continues to Red Pond, for instance, can be explained as having originated during overwash and having served as an inlet for a short while afterward. (2) Likewise there is no 
a

North

PINK SAND

Contains many

Homotrema rubrum grains
Fine; Capped Very fine with Inferred typically with mud laminae; gradation from burrowed shell beside Bumber pink sand into by crabs layer Well Pond soft sand

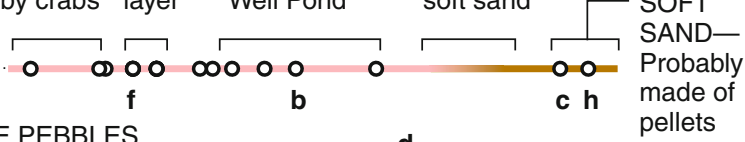

SHELLY SAND WITH LIMESTONE PEBBLES Beneath Bumber Well Pond

Fig. $7 \mathrm{a}$

Fig. $7 d-f$

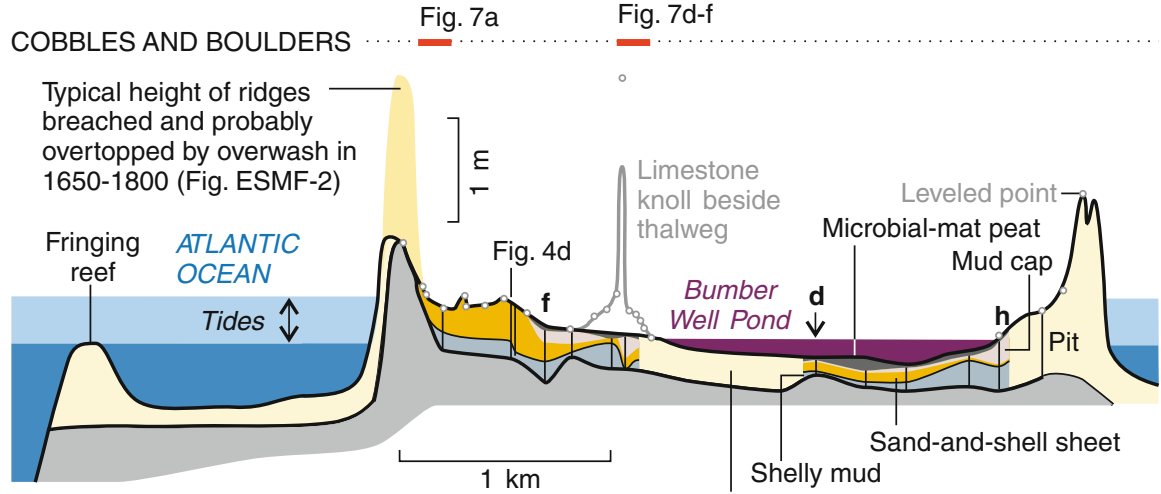

Vertical exaggeration x 500 Holocene deposits, undivided
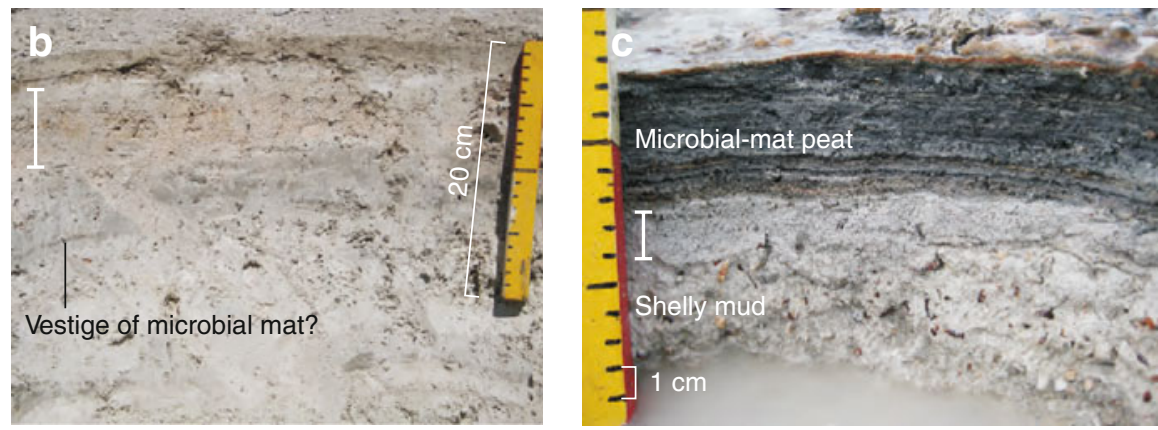

Microbial mats

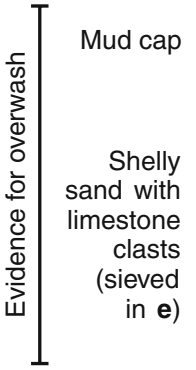

Shelly lime mud
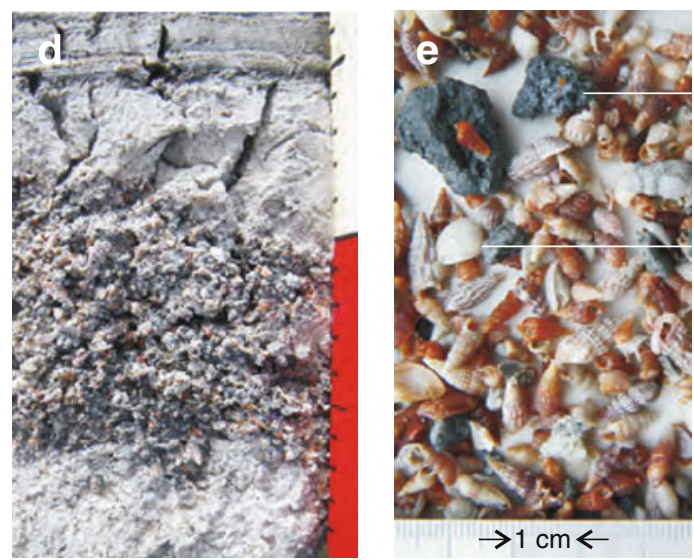

Angular black

limestone pebble

Anomalocardium

valve

Molluscan

assemblage

dominated by

cerithid gastropods 

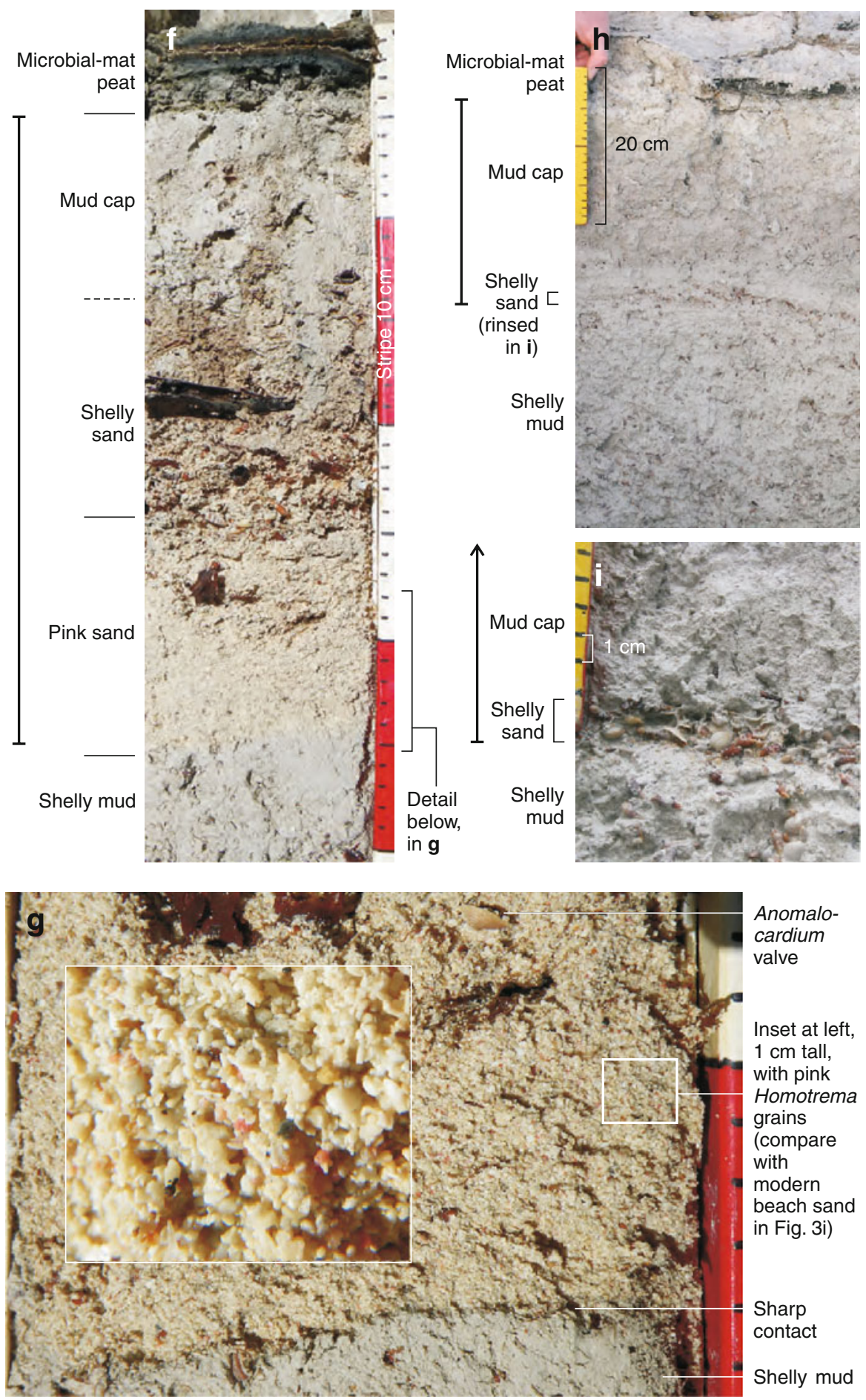

Anomalo-

cardium

valve

Inset at left,

$1 \mathrm{~cm}$ tall,

with pink

Homotrema

grains

(compare

with

modern

beach sand

in Fig. 3i)

Sharp

contact

Shelly mud

Fig. 6 continued 
need for immediately pre-overwash inlets at Windlass Bight to keep a marine pond from going hypersaline if, as is likely, sufficient connection with the sea existed elsewhere. On the island's southern side, its leeward shore, an inlet was present in 1831 (Fig. 2d) and remains open today (Fig. 5). Nearby, former lee-side connections are suggested by elongate swales of muddy sand south of Point Peter Pond (lavendar fingers in Fig. 5). (3) Immediately pre-overwash inlets at Windlass Bight are improbable because the Bight's shore is a windward one that lacks any inlet today and lacked one in 1831 as well (Fig. 2d). Currents and waves built beach ridges that sealed off every breach (Fig. 5). Tidal flows, driven by a tidal range of $0.5 \mathrm{~m}$, failed to keep even the largest breaches open.

Another alternative explanation for the breaches is that they originated as relief on the underlying limestone. This explanation fails because the breaches at Windlass Bight are wider and rounder than the grooves of spur-and-groove bathymetry (Fig. 3c, d), and because the breaches contrast with the circular sinkholes that are Anegada's only conspicuous signs of karst (examples in southern part of Fig. 5).

\subsubsection{Examples near Keel Point}

Though we scarcely checked them in the field, we could not help but plot the breaches southwest of Keel Point when compiling the sketch map (Fig. 2a). Their margins are represented by solid black lines, best seen in the inset enlargement (Fig. 2b).

By size and shape, they can be divided into two groups. One group is composed of a few isolated breaches tens of meters long and wide. Its northern limit adjoins line 1 in Fig. $2 \mathrm{~b}$. The other group coalesces in a broad swath that heads farther seaward, near line 2, and extends southward into a channel-like arm of Flamingo Pond. The swath probably coincides with the pond mapped north of Flamingo Pond in 1831 (Fig. 2c) and with the area where, according to Schomburgk (1832), the 1819 hurricane blocked an inlet (Sect. 6.2.2).

\subsection{Sheet of sand and shells}

Anegada's most widespread depositional evidence for overwash is a sheet dominated by sand and shelly sand. It commonly contains limestone pebbles and, beneath salt ponds, is capped with mud. We found this sheet north of and beneath Red Pond and Bumber Well Ponds, along the east side of the entire length of Bumber Well Pond, and on a fringe of Point Peter Pond (color-filled dots and squares in Fig. 5). It comprises several lithologic facies that we lump in Fig. 6a on the basis of shared stratigraphic position between saltpond microbial mats above and marine-pond shelly mud below (Sect. 6.1; examples, Fig. $6 \mathrm{~b}-\mathrm{g}$ ), and on the basis of radiocarbon ages (Sect. 6.2; Fig. 8). Where the shelly mud is absent the sheet rests directly on limestone.

The most widespread facies consists of sand with grains of Homotrema rubrum (Fig. 6b, f, g). We call this sand pink although it is commonly tan; African dust, carried to the Caribbean by trade winds (Prospero and Lamb 2003), may contribute to the tan color. Tracing it southward from the breachs beside Windlass Bight, we found the pink sand as much as $1 \mathrm{~km}$ inland beneath Red Pond and as much as $2 \mathrm{~km}$ inland along margins of Bumber Well Pond (Fig. 5). Along the cross-section line in Fig. 6, it decreases southward both in maximum thickness (from nearly a half meter to a few centimeters) and in grain size (from fine sand to very fine sand that contains laminae of mud). These trends suggest that the pink sand was derived from the north. There it has two potential sources evaluated by Pilarczyk and Reinhardt (2010): beach deposits removed from the breaches beside Windlass Bight and the sandy floor of the reef flat. 
Also widespread is sand or mud crowded with the detrital shells of mollusks (blue dots, Fig. 5). These form a layer that locally caps the pink sand north of Bumber Well Pond (blue-over-pink symbols in Fig. 5; example, Fig. 6f). The taxa include those (Jarecki 2003) found dead at Anegada's salt ponds, along with a few others described by Reinhardt et al. (2010). The assemblages resemble, and were probably derived from, those in the shelly mud of the bygone marine pond (Sect. 6.1.1).

Beneath the Bumber Well Pond, which occupies a trough flanked and underlain by limestone (Fig. 5), the sand and shell unit darkens overall from limestone clasts. Most are angular granules or pebbles (Fig. 7d, e). Limestone pebbles are also present, but only sparsely, in the pink sand to the pond's north and the soft sand at its southwestern end, and they are absent in the facies of very fine pink sand on the trough's east side (Fig. 7b, c). The trough provided both a ready source for the pebbles and narrow cross-section for flows that could move them.

Easily crushed grains abound in the sand-and-shell unit beside southern Bumber Well Pond and Point Peter Pond (termed "Soft" in Fig. 5 and SOFT SAND in Fig. 6a; examples, Fig. 6c, i). These may have been derived from pellets in the underlying shelly mud.

Lime mud caps the sand-and-shell unit in most places beneath and on the margins of the perennial parts of Red and Bumber Well Ponds (Fig. 4b; Fig. 6d, f, h; ESMF 3-5). It ranges in thickness from a few centimeters to a few decimeters. It locally contains sandy or shelly laminae (sites 16 and 19, Fig. 8d). Where undisturbed by crabs or mangrove roots it contains entire leaves (Fig. 8a; ESMF 4d) and the claws of fiddler crabs. It lacks growthposition mollusks except in the lowest several centimeters of the unusually thick mud cap at the southwest end of Bumber Well Pond, where it contains cerithids that may seek escape from the overwash or marine-pond deposits beneath (ESMF 5d). The mud's nearest and most probable source was the marine pond that had been covering much of western Anegada's interior at the time of the inferred overwash. The cap can be explained most simply by settling of marine-pond mud that had been put into suspension at the time of the inferred overwash. The sandy and shelly laminae within the cap suggest that energetic pulses interrupted this settling.

\subsection{Boulders}

The western interior of Anegada contains fields of angular cobbles and boulders (Fig. 2a). We noticed two in the narrows southeast of Bones Bight Pond, one beside Point Peter Pond, one near beside southeast Windlass Bight (Fig. 7a), one in northeast Red Pond (Fig. 7b, c), one often flooded by northern Bumber Well Pond (Fig. 7d-f), and a strip of angular cobbles along the west side of the narrows at the south end of Red Pond (location, Fig. 5). We also noted solitary coral boulders, some of them probably derived from the limestone but others perhaps derived from Holocene reefs (example, ESMF 7).

Some of the fields are elongated (Fig. 5). Most extend from their probable sources, such as the limestone peninsula in Fig. $7 \mathrm{~b}$ and $\mathrm{c}$, in directions implying transport that was southward overall but turned eastward or westward with local topography (arrows, Fig. 2a). Watt et al. (2010) and Buckley et al. (2010), who examined the fields near Windlass Bight and Bumber Well Pond, present further evidence that these were emplaced by southward transport. 


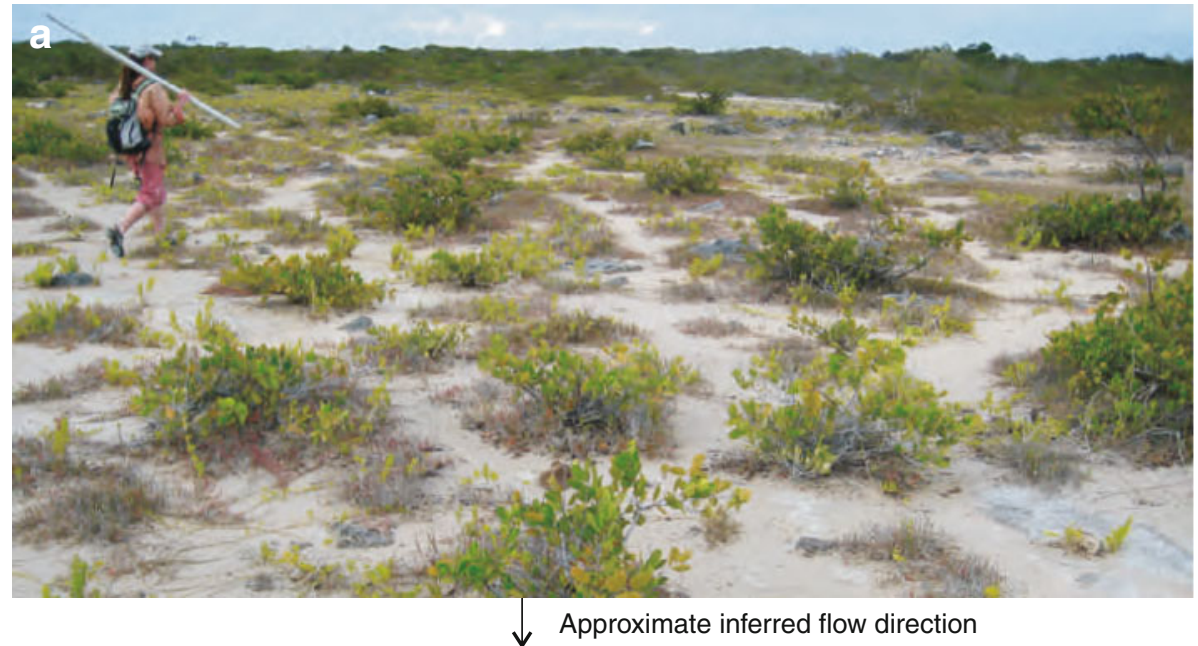

$\begin{array}{llll}\begin{array}{l}\text { Site of shoreline } \\ \text { notch in Fig. } 4 \mathrm{~g}\end{array} & \begin{array}{l}\text { Tip of limestone } \\ \text { peninsula }\end{array} & \begin{array}{l}\text { Cobbly fan southwest of } \\ \text { limestone peninsula }\end{array} & \begin{array}{l}\text { Red } \\ \text { Pond }\end{array}\end{array}$

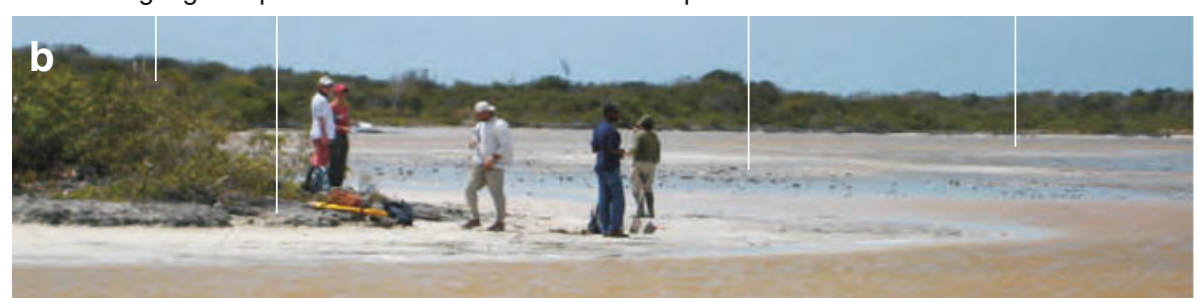

Approximate inferred flow direction

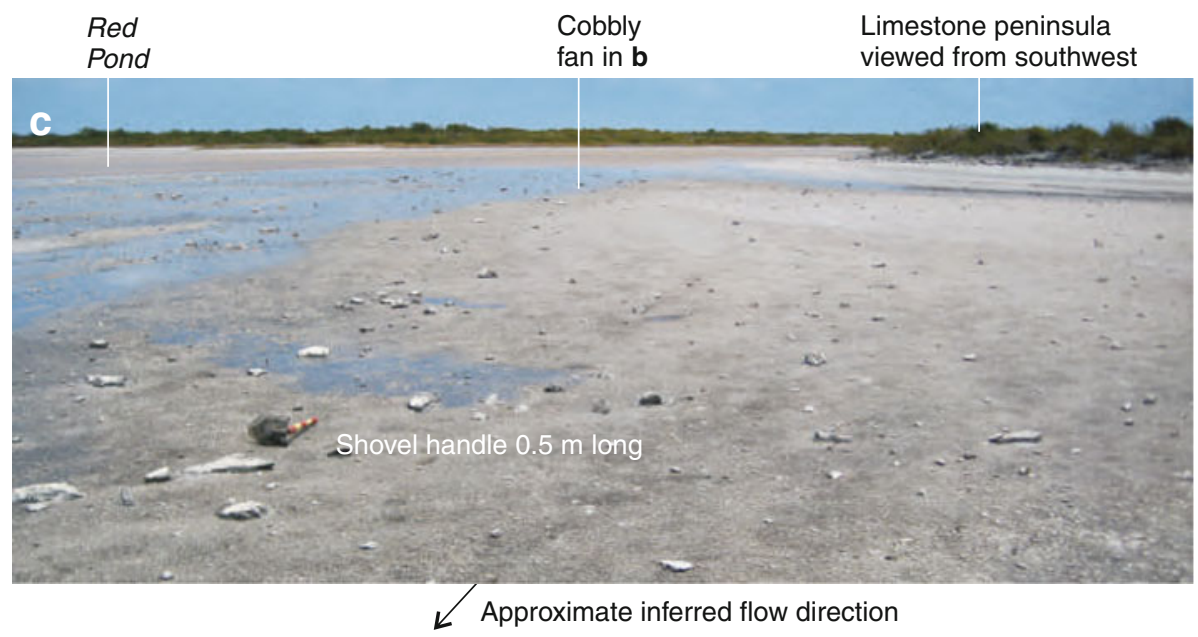

Fig. 7 Fields of cobbles and boulders. Locations, Fig. 5. a Near Windlass Bight. Muddy sand surrounds gray limestone boulders. b, $\mathbf{c}$ Beside northeast Red Pond. d-f Near north end of Bumber Well Pond 


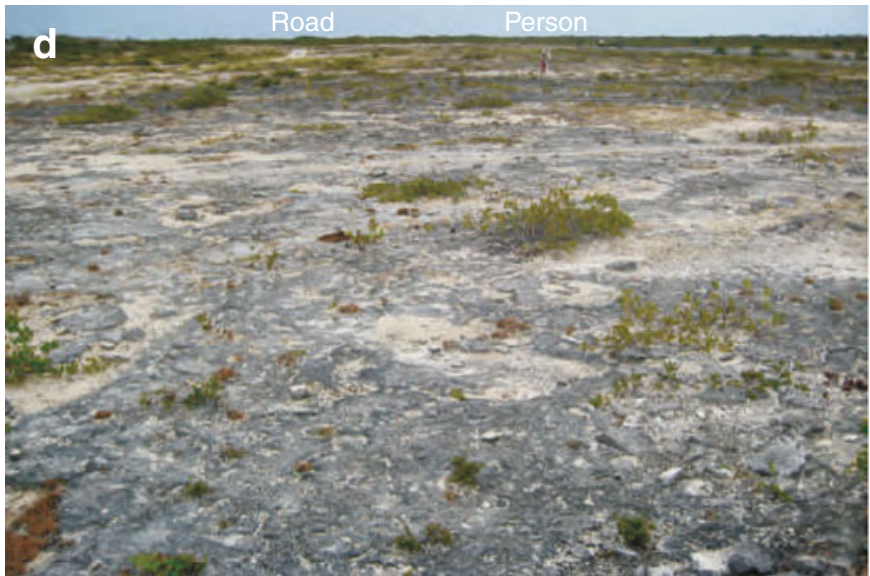

\section{Approximate \\ inferred flow \\ $\downarrow$ direction in d-f}

Bare limestone

pavement on north-

facing slope of

limestone knoll in Fig.

6a. View to north
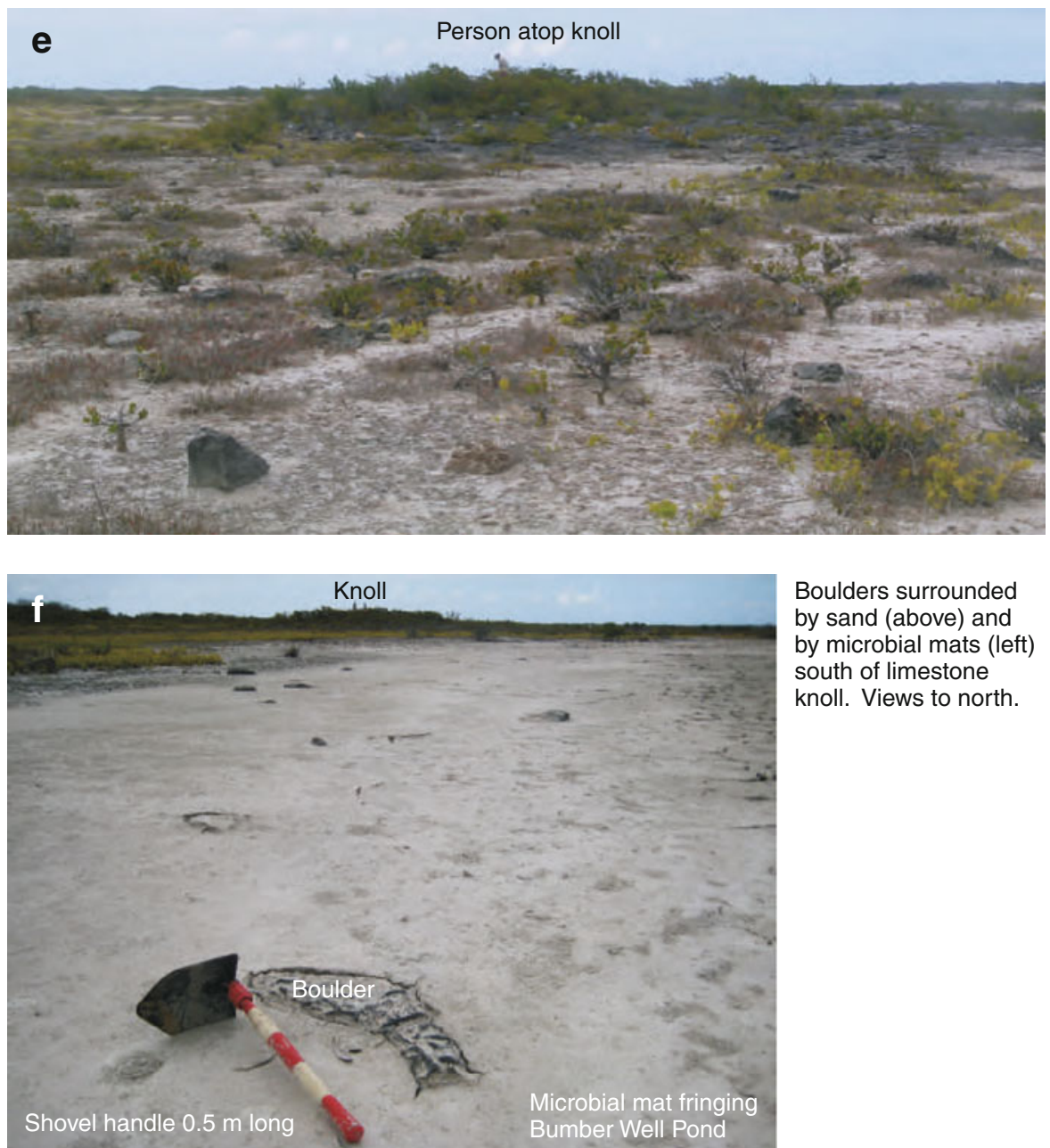

Boulders surrounded by sand (above) and by microbial mats (left) south of limestone knoll. Views to north.

Fig. 7 continued 


\section{Time of overwash}

To summarize the relative and numerical dating detailed below: Much of Anegada's overwash deposition dates stratigraphically to the time when a marine pond in the western part of the island ceased to support mollusks and turned into a patchwork of salt ponds dominated by microbial mats. The time of this environmental change, and of the inferred overwash itself, has been dated numerically to the decades between 1650 and 1800 . Radiocarbon ages of leaves and twigs in the mud cap suggest that the inferred overwash happened no early than the middle of the 17th century AD. Written records of human settlement at Anegada probably rule out overwash in the 19th and 20th centuries.

\subsection{Relative ages from stratigraphy}

Stratigraphy shows that the sheet of sand and shell was laid down, and that cobbles and boulders were moved, on the muddy and shelly floor of a shallow bay that became salt ponds soon thereafter. The presence or absence of this marine pond's deposits provides discordant relative ages on two of the breaches.

\subsubsection{Evidence for marine pond}

The shelly mud rests on limestone beneath Red and Bumber Well Ponds but also at higher levels that are still below today's high tides of the surrounding sea; the mud extends even beneath parts of the boulder field near Windlass Bight Fig. 6a). Its preserved thickness ranges from a few centimeters to more than a meter. It typically lacks bedding, probably because of bioturbation.

The fossil assemblage of the shelly mud is dominated by cerithid gastropods, the bivalve Anomalocardia, and several other molluskan taxa that similarly dominate the shelly part of the sand-and-shell sheet (Reinhardt et al. 2010; Fig. 6d-i). Most of the shell deposited by the inferred overwash may have thus been derived from the marine pond.

Though not saline enough to exclude its mollusks, the marine pond had margins that supported microbial mats. Probable vestiges of mats underlie the pink sand east of Bumber Well Pond (Fig. 6b), and we found well-preserved mat fragments in the sand-and-shell sheet at the pond's southwest end (in the section shown in Fig. 6i and ESMF 5c, d).

The bay may have originated at least 2,000 years ago and perhaps as much as 4,500 years ago. Cerithid gastropods in the shelly mud just below the sand-and-shell sheet gave discordant ages as great as 1,900-2,300 calibrated years ago, and articulated Anomalocardia within a northern part of the sand sheet gave discordant ages as great as 4,500-4,700 years ago (Fig. 8d; ESMT 2). These great ages, if not the artifacts of old carbon from Anegada's limestone, can be explained by bioturbation in the shelly mud and by deep overwash scour in the source area for the northern part of the sand-and-shell sheet.

\subsubsection{Relative age of overwash deposition}

The depositional evidence for overwash, where not resting directly on limestone, overlies the shelly mud of the marine pond. This relative age applies to the sand-and-shell sheet, which overlies the shelly mud directly and abruptly (Fig. 6c-i, Fig. 8d, and ESMF 3), and to boulders and cobbles whose stratigraphic positions have been checked: 
Fig. 8 Radiocarbon and documentary evidence on the time of catastrophic overwash. a Generalized stratigraphic column showing setting of most of the dated materials. b Radiocarbon ages, converted into two-standard-deviation ranges in calibrated years AD or BC. Symbols on ends of range bars relate the age of the dated material to the time of the inferred overwash. See ESMT 2 for ages in radiocarbon years, field-site numbers, and lab-sample numbers. c Age constraints from historical records discussed further in ESMT 1. d Columnar sections showing stratigraphic settings of most of the ages plotted in b. e Index map for the dated samples

(1) In the two fields of boulders and cobbles that they examined near Windlass Bight and Bumber Well Pond, Watt et al. (2010) surveyed a total of 161 clasts. Though they did not necessarily observe the lowest parts of the clasts' keels, they found 27 of the clasts resting on bare limestone, 54 on top of the sand-and-shell sheet, 77 partly buried within the sand sheet, and none extending into shelly mud beneath the sandand-shell sheet.

(2) A brain-coral head between the two boulder fields is embedded in sandy deposits probably correlative with the sand-and-shell sheet at a site where the marine-pond deposits were either absent or scoured during overwash (ESMF 7).

(3) Angular cobbles along the narrows at the south end of Red Pond rest on eroding pedestals of shelly mud near site 13 (location, Fig. 8d, e; about $5 \mathrm{~m}$ west of the pit in ESMF 4).

The sand-and-shell sheet at the Red Pond narrows rests directly and abruptly on probable correlative of the shelly mud: the peaty mud of a red-mangrove swamp (ESMF 4). This swamp likely fringed the marine pond at a site where mangroves are now excluded by high salinity.

\subsubsection{Relative age of overwash erosion}

If the breaches in the beach ridges south of Windlass Bight originated with the marine pond's demise, no shelly bay mud should be present in the breach fill. We looked for shelly mud at one site for each of two breaches. One of the sites showed shelly mud while the other did not.

We found shelly mud in the breach marked by the northeasternmost playa beside Windlass Bight (ESMF 6a; location, Fig. 5). There, microbial mat peat above the mud is in turn overlain by an overwash deposit composed of sand with a mud cap. Perhaps the breach originated before the demise of the marine pond and contained a fringing salt pond, separate from the marine pond, at the time when the sand and its mud cap were laid down.

The site without the shelly mud adjoins the large breach in Fig. 3d (site 31). It showed a well-stratified sequence containing microbial mats to $0.5 \mathrm{~m}$ depth, leaf layers to depths of $1.3 \mathrm{~m}$, and fine sand beneath (ESMF 6b-h). Except for an ambiguous radiocarbon age, the site yielded no evidence for deposition before the bay's demise. Two reliable ages imply deposition after the bay's demise. These ages, measured on a leaf and a mangrove propagule from one of the shallowest leaf-rich layers (ESMF 6f,g), are no greater than those of leaves and twigs from the mud cap of the inferred overwash deposit (Fig. 8b). However, bulk detrital peat lower in the section gave a distinctly earlier age. We think this age is ambiguous because the sample may have included material much older than the time of deposition. 
a

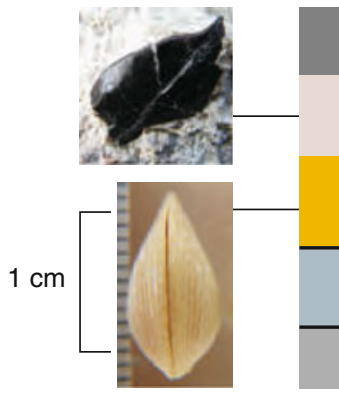

Microbial-mat peat of hypersaline ponds

Mud cap

Interpreted as overwash deposits

Sand, shell, or both

Shelly mud and peaty mud of marine pond

Limestone

b

\begin{tabular}{l|l} 
Ages \\
grouped \\
by \\
material \\
dated \\
and by \\
its unit \\
in a
\end{tabular}

Plant detritus likely younger than mud cap (site 31)

Leaves $(8,13,15,16,105)$ and a twig $(19)$ in mud cap

Articulated bivalves in sand and shell unit $(13,14,16)$

Not plotted: two ages 2400-2700 BC

Mangrove roots below sand and shell unit (13)

Gastropods below sand and shell unit (8)

$\longmapsto$
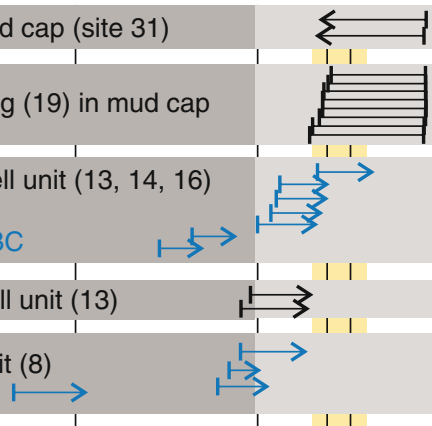

Ambiguous (microbial mat peat at 19 , leafy peat at 31 ) $-500$

$B C / A D$

1000

Time of inferred overwash is earlier than $(\longleftarrow$ ), within $(\longmapsto)$, or later than $(\longmapsto)$ some or all of the age range.

Ranges in blue exclude uncertainty in carbon-reservoir age.

C

Inferred time window for catstrophic overwash at Anegada

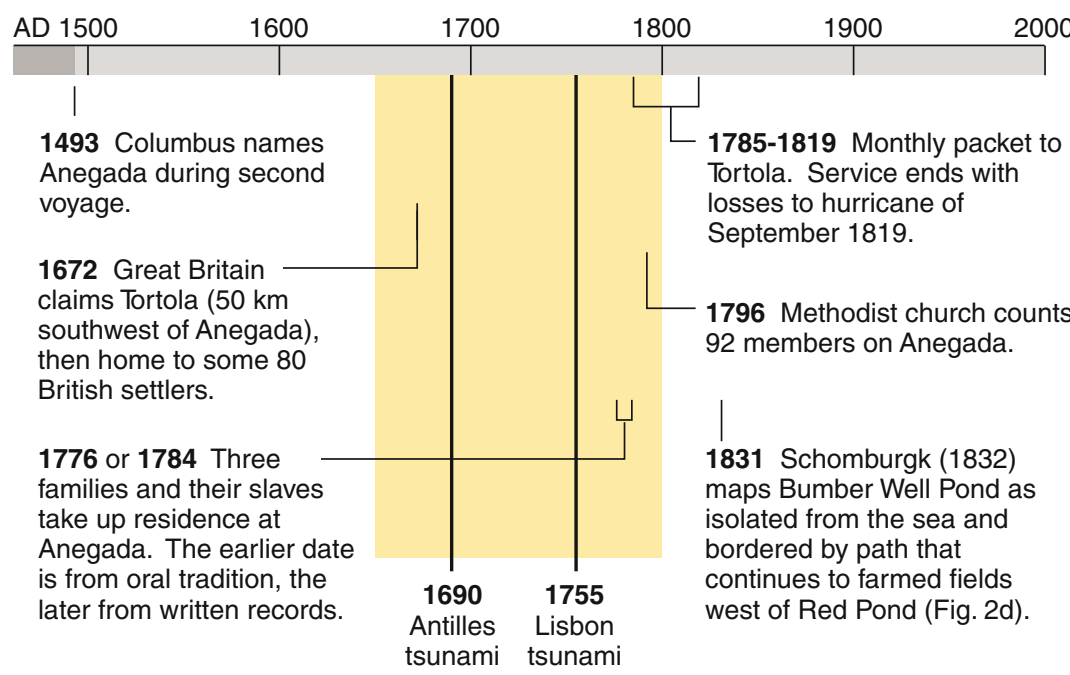




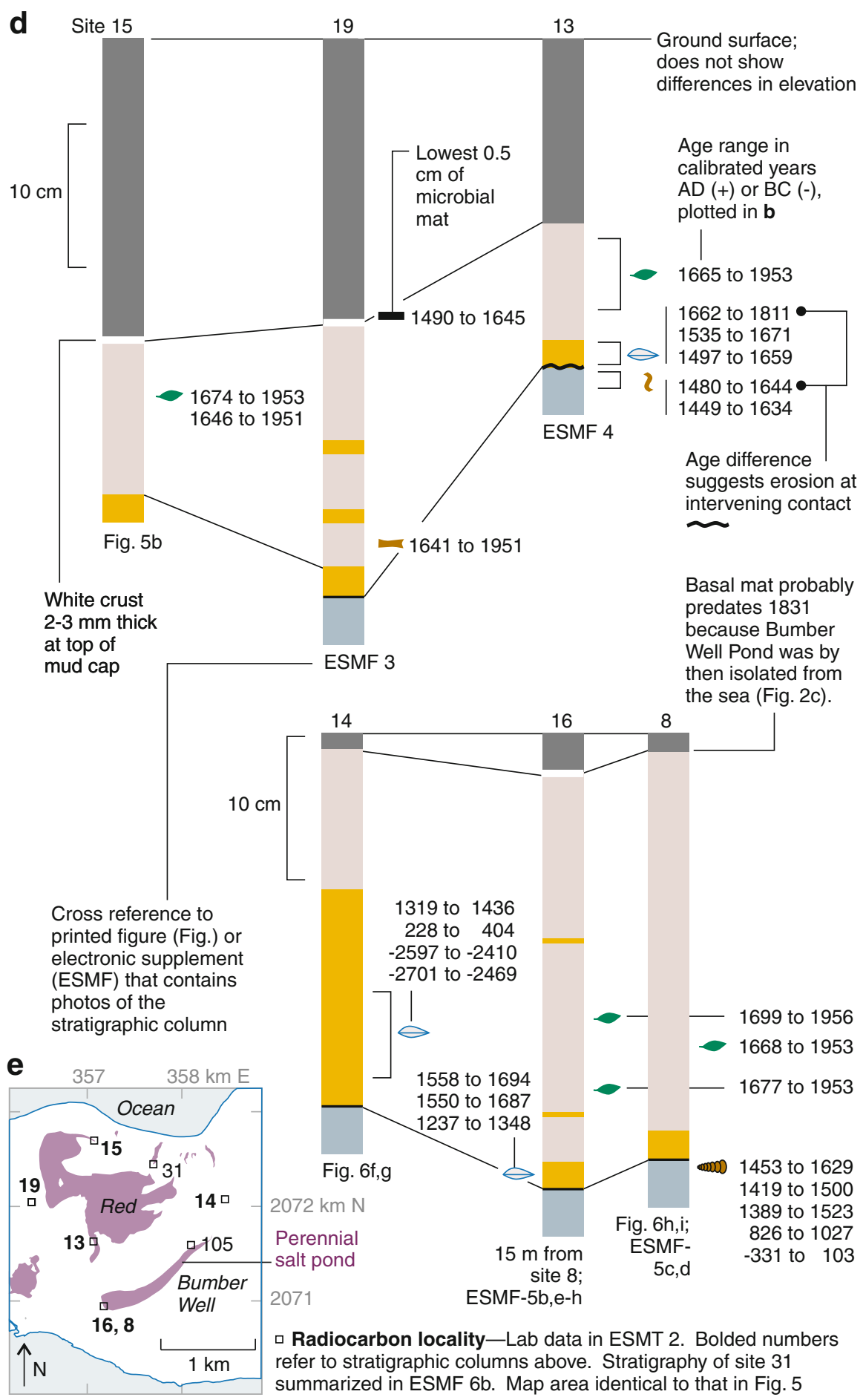

Fig. 8 continued 


\subsubsection{Causes of the marine pond's demise}

Many Caribbean salt ponds probably originate through progressive enclosure of former bays (Jarecki and Walkey 2006; Dix 1999). Such enclosure at Anegada can be explained by the westward extension of beach ridges along the island's windward and leeward shores (Fig. 2). By the time of the inferred overwash between 1650 and 1800, Anegada's marine pond was probably well on its way to becoming salt ponds, as shown by the evidence for fringing microbial mats (Sect. 6.1.1).

Anegada's final shift to hypersaline conditions, however, probably resulted, counterintuitively, from the catastrophic overwash that breached beach ridges on the island's north side. This overall cause-and-effect is shown most clearly by the presence of the sand-andshell sheet at the contact between the shelly mud of the marine pond and the laminated microbial-mat peat of the ensuing salt ponds. Overwash might have caused the environmental change directly by building fans southward into inlets that may have connected the bay to the sea on the island's south side. It may also have deposited enough sand inside the island to reduce the marine pond's tidal prism, thereby allowing beach sand to constrict such an inlet or inlets. In addition, by moving sand on shallows offshore of the island, the overwash might have provided later waves and currents with sand that soon restricted such inlets.

\subsection{Numerical dating}

\subsubsection{Radiocarbon ages}

Radiocarbon ages suggest 1650 as the earliest likely time of the inferred overwash (Fig. 8). This estimate is based on analyses of leaves and twigs in the mud cap of the sand-and-shell sheet, but it is also consistent with limiting-maximum ages from shells and plant remains at lower stratigraphic levels (Fig. 8a, b; ESMT 2).

The materials that date the inferred overwash most closely are leaves from the mud cap. Because these leaves are both entire and delicate, they were probably alive in the last year or two before the inferred overwash suspended them. As part of the mud cap, the leaves settled out of still water as the overwash event concluded. For these reasons, we infer that the radiocarbon in the leaves started to decay in the last year or two before the overwash event itself. Furthermore, because the carbon in the leaves came directly from the atmosphere, the leaf ages do not need the marine-reservoir correction that adds uncertainty to the shell ages (Sect. 2). We use 1650 as a round-number maximum age of the overwash because the 95-percent confidence interval of the oldest of the leaf or twig ages extends back to 1646 (NOSAMS-71376, measured on a forked twig), while the youngest extends back to 1699 (NOSAMS-71378, on fragments of one leaf or several leaves; ESMT 2).

Sample ages below the mud cap limit the overwash time loosely because their radiocarbon clocks may have begun to tick decades or even centuries before the inferred overwash. These materials include shells collected from the shelly bay mud, shells collected from the overwash unit but also derived from that mud, and roots of mangroves that may have been exhumed by erosion during the overwash (Fig. 8d).

\subsubsection{Documentary records}

The written history of Anegada's settlement probably precludes catastrophic overwash after 1800 (Fig. 8; ESMT 1). Three resident families arrived in 1776 according to oral 
tradition and were noted in writing in 1784. The island's population included 92 Methodists in 1796 and totaled 197 in 1811 . The map surveyed in 1831 shows paths through overwashed areas that include the southwest end of Bumber Well Pond and the outlet of Red Pond (Fig. 2d). A pond on the map also provides evidence that the survey postdates the breaches beside Windlass Bight (Sect. 6.3.2).

A potential problem with this documentary evidence is Schomburgk's (1832) statement that a hurricane closed off a northern inlet to one of Anegada's salt ponds in 1819. Suppose the inlet had fed the bay marked by the shelly mud - the bay that met its demise soon after the inferred overwash (Sect. 6.1.4). Might both the overwash and the bay's demise therefore date from 1819? The 1819 hurricane was a documented catastrophe. In Tortola it took nearly 100 lives, put plantations out of business, and precipitated the end of a monthly mail boat that had served Tortola since 1785 (Dookhan 1975).

Schomburgk's statement, however, has several difficulties of its own. He was not himself at Anegada for the 1819 hurricane but instead learned of it secondhand, 12 years later. His report does not name his sources, nor does it identify the inlet or the connected pond. His map shows one strong candidate for the inlet, the linear pond near Keel Point (Fig. 2d), but this pond is in an area of numerous beach ridges (Fig. 2b). The ridges there, and also those outboard of the breaches of Windlass Point, demonstrate the ease of blocking low places along the island's windward shore.

\subsection{Overwash recurrence}

\subsubsection{Breaches and deposits from the time of the marine pond}

Our reconnaissance did not include a careful search for evidence of overwash prior to the advent of western Anegada's large salt ponds. Such evidence may include the inner group of breaches near Keel Point (Sect. 5.1.1) and the breach underlain by shelly mud beside Windlass Bight (Sect. 6.1.3).

We see little chance of finding kilometer-long sheets of sand and shell that survive from the time of the marine pond. That bay supported burrowing animals that mixed up its bottom sediments, as shown by a widespread lack of distinct bedding in the shelly mud and further suggested by the roughly 1,500 year age range among the cerithid shells immediately beneath the sand-and-shell sheet at the southwest end of Bumber Well Pond (sites 8 and 13 of Fig. 8d).

Deposits beyond the microbial mats of the perennial ponds continue to be bioturbated today by fiddler crabs (Sect. 4.3.2). We sought to escape the crabs by coring sinkholes southeast of Bumber Well Pond (including the two sinkholes plotted in Fig. 5) but found no field evidence for overwash in these sinkholes.

\subsubsection{Breaches since the early 1800 s}

We recognized no erosional evidence for 19th- or 20th-century recurrence of widespread overwash of Anegada's north shore. But we did find localized deposits that may record surges and waves from Red Pond driven from the south by counterclockwise vortex winds in the trailing quadrants of west-trending hurricanes.

Hurricane Donna cut no breaches through beach ridges of Windlass Bight. The absence of breaches from 1960 can be seen by comparing airphotos of Windlass Bight taken in 1945 and 1969 (Fig. 3a, b). Donna failed even though its winds at Anegada blew hard from the north as the storm approached from the west (storm track, Fig. 1a; eyewitness accounts, 
ESMF 1a-c) - a wind direction expected of the counterclockwise vortext of a west-moving tropical cyclone in the northern hemisphere (Coch 1994).

Schomburgk's map surveyed in 1831 shows a small pond in the vicinity of the beaches beside Windlass Bight (Fig. 2d). This pond probably sits in the breach at site 31 (Fig. 8e; ESMF 6) or in one of its neighboring breaches. Though the sea may have coursed through many of Anegada's breaches on more than one occasion, the mapped pond shows that at least one of the main breaches beside Windlass Bight predates 1831.

We found no widespread sheet of sand and shell bounded by microbial mats of Red Pond, Bumber Well Pond, or the small ponds held by breaches to their north (Fig. 6c). However, between the mat laminae we commonly found clastic interbeds probably derived from nearby expanses of sandy, shelly ground. These may amount to stratigraphic records of hurricanes, as illustrated by deposits between mats in the breach at site 31 (Sect. 6.1.3). Their ready source lies a few tens of meters to their south on the bare sandy divide that rises a few tenths of a meter between Red Pond and the breach (ESMF 6c,d).

When vortex winds at Anegada blow from the south, as they did after Donna's eye had passed to the island's west, they can drive a storm surge onto the island's south shore (ESMF 1a-c). In Red Pond, the resulting surge and waves can easily wash over the divide, a few tenths of a meter high, into the breach that includes site 31 . There they can then lay down sand and shell on mats of the breach pond (aerial views, Fig. 3a, d; ground views, ESMF 6c, d).

\section{Tsunami or storm?}

The cause of the inferred overwash between 1650 and 1800 needs to explain:

1. Attack mainly from the north-Evidenced by southward tapering and shoaling of breaches (Sect. 5.1.1), southward tapering and fining of the pink sand (5.2), and boulder fields that extend southward from their probable sources (5.3).

2. North shore height of $3 \mathrm{~m}$ or more-To cut breaches into beach ridges south of Windlass Bight (5.1.2).

3. Sediment transport more than $1 \mathrm{~km}$ inland-Evidenced by the $1.5 \mathrm{~km}$ extent of the pink sand (5.2), the inland boulders embedded in it (5.3), and the pebbly shelly sand beneath Bumber Well Pond (5.2).

4. Uniqueness in the last few centuries or more-Evidenced by dating to the probable time window 1650-1800 (6.2) and by Anegada's probable lack of a comparable catastrophe since (6.3.2).

We do not attempt, in this paper, to distinguish between tsunami and storm on the basis of these findings. It is premature to attempt the distinction without further evidence on the sources of fossils in the sand-and-shell sheet (Reinhardt et al. 2010; Pilarczyk and Reinhardt 2010), the size and spacing of boulders (Watt et al. 2010; Buckley et al. 2010), and computer simulations of storm surges, storm waves, and tsunamis. Here, we merely state the tsunami and storm hypotheses as a pair of scenarios:

A tsunami is heading southward or southwestward toward Anegada. It loses little energy to transit of a continental shelf because it remains in deep water until just $10 \mathrm{~km}$ from the island's fringing reef (Fig. 1a). From there, a tsunami wave of long period may pour over the reef and may build up, like a rapidly rising tide, against beach ridges $2-3 \mathrm{~m}$ high beside Windlass Bight. Pouring over and cutting through the ridges, it entrains pink beach-ridge sand and transports it southward into the marine pond. Along the way it moves boulders 
from outcrops and erodes some of the marine pond's floor. Meanwhile, the same wave also curls around Anegada and, now invading the marine pond from the south, move pond mollusks northward, locally emplacing them on top of the pink sand north of Bumber Well Pond (Fig. 6f). As the tsunami wanes, lime mud it has suspended from the marine pond settles out as a cap. Uncertainties about tsunami sources-whether near Lisbon or at the Antilles subduction zone-provide tsunami modelers with enough leeway to simulate the overwash.

An uncommon hurricane is heading westward toward Anegada. It will soon overcome Windlass Bight's natural protections against storm surge and storm waves from the north, spawn tornadoes that create the island's inland fields of boulders, and conclude with a strong surge from the south. The narrow shelf to Anegada's north limits storm-surge heights on the island's north side (Sect. 3.3), and storm waves break on the fringing reef $1.5 \mathrm{~km}$ north of the beach ridges of Windlass Bight (Sect. 4.1). The storm nevertheless builds a hydraulic head north of the beach ridges. This head overtops and incises the ridges, breaching them much as modern hurricanes have cut lineations and channels across barrier islands (Morton and Sallenger 2003). It also manages to drive southward flows that move sand $1.5 \mathrm{~km}$ inland. If these flows fail to create inland fields of boulders, a tornado moves the stones, as did a waterspout in New Zealand (de Lange et al. 2006). The boulders move southward because the front-right quadrants of hurricanes commonly contain tornadoes (Novlan and Gray 1974) that move in the same direction as the vortex winds (McCaul 1987; McCaul et al. 2004). As the hurricane moves west of Anegada the vortex winds of its trailing quadrant drive a storm surge ashore from the south. The surge creates currents stronger than those through which eyewitnesses waded during Hurricane Donna (Sects. 3.3 and 6.3.2). This northward currents deposit marine-pond mollusks on top of the pink sand north of Bumber Well Pond. Mud stirred up by storm waves and currents settles out at the end, as did mud suspended by Hurricane Donna in Florida (Ball et al. 1967).

\section{Inferred history}

Most of the area of west-central Anegada stood above postglacial sea level until the last several 1,000 years, when the postglacial tides finally surmounted the limestone platform now covered by Red and Bumber Well Ponds. Though probably flanked by beach ridges, the resulting pond maintained enough of a connection with the sea to support mollusks. The ridges may have been widely breached by overwash at least once during the time of this marine pond, but stratigraphic evidence for such overwash has probably been lost to burrowing crabs.

The marine pond persisted through the first century or more of European exploration and settlement of the Caribbean. It was present when Columbus during his second voyage named Anegada in 1493. It probably lasted until sometime between 1650 and 1800. Its demise coincided closely enough with catastrophic overwash that the former was probably caused, directly or indirectly, by the latter.

This catastrophic overwash came mainly from the north. It created or at least freshened breaches in the beach ridges along the island's north shore. It washed distinctively pink sand southward as much as $2 \mathrm{~km}$ into the shallow bay, and it locally capped the sand with shells it entrained from the bay-bottom mud. It also moved limestone cobbles and boulders across the bay floor for tens to hundreds of meters, forming fields pendent to outcrops from which the clasts were probably derived. It concluded by raining out lime mud that it had suspended along with whole leaves, twigs, and fiddler-crab claws. 
The marine pond met its demise soon after this overwash. Paradoxically, the same overwash that breached Anegada's beach ridges on the north resulted in the blockage of the pond's inlet or inlets. The pond soon shrank into several hypersaline ponds; the mollusks died, and microbial mats blanketed the ponds' perennial floors. Though fiddler crabs took up residence in seasonally flooded sand, their exclusion from the perennial salt ponds helped preserve stratigraphic evidence of the overwash.

The overwash probably happened after 1650 and before 1800. It may have resulted from a known Caribbean tsunami in 1690, the Lisbon tsunami of 1755 , or a Caribbean tsunami unknown from written records. If instead it resulted from a hurricane, the storm's effects far exceeded those of any storm at Anegada since 1831.

Acknowledgments The government of the British Virgin Islands granted us unrestricted access to Anegada's salt ponds, use of airphotos, and guidance from its specialists in disaster management, surveying, and natural science. Among them we especially thank Cynthia Rolli, Rondell Smith, Shannon Gore, and Dylan Penn. Lianna Jarecki shared her comprehensive knowledge of Anegada's salt ponds. Anegadans who helped us with island history include Darvin Potter and Doris Faulkner. For help in locating old maps of Anegada we thank Luisa Martin-Meras, Directora Tecnica del Museo Navan de Madrid; María Antonia Colomar Albajar, Subdirectora del Archivo General de Indias, Sevilla; Pilar Llanes Estrada and Jose-Luis Granja, Universidad Complutense de Madrid; and José Martin Davila from the Real Observatorio de la Armada. Caitlin Herlihy and Alejandra Rodriguez assisted with field work. Jeffrey List, Jeffrey Donnelly, Stella Kortekaas, David Long, and two anonymous referees provided suggested that improved the manuscript. The work was supported in part by the Nuclear Regulatory Commission under its project N6480, a tsunami-hazard assessment for the eastern United States.

Open Access This article is distributed under the terms of the Creative Commons Attribution Noncommercial License which permits any noncommercial use, distribution, and reproduction in any medium, provided the original author(s) and source are credited.

Note added in proof Hurricane Earl was at category 4 when its eye passed $30 \mathrm{~km}$ to the north of Anegada on August 30, 2010 (http://www.nhc.noaa.gov/2010atlan.shtml).

\section{References}

Ball MM, Shinn EA, Stockman KW (1967) The geologic effects of Hurricane Donna in south Florida. J Geol 75:583-597

Baptista MA, Miranda JM (2009) Evaluation of the 1755 earthquake source using tsunami modeling. In: Mendes-Victor LA, Oliveira CS, Azevedo J, Ribeiro A (eds) The 1755 Lisbon earthquake: revisited. Springer, Dordrecht, pp 425-432

Baptista MA, Miranda JM, Luis JF (2006) In search of the 31 March 1761 earthquake and tsunami source. Bull Seismol Soc Am 96:713-721

Barkan R, ten Brink US, Lin J (2009) Far field tsunami simulations of the 1755 Lisbon earthquake: Implications for tsunami hazard to the U.S. East Coast and the Caribbean. Mar Geol 264:109-122. doi: 10.1016/j.margeo.2008.10.010

Bernard P (1988) Subduction and seismic hazard in the northern Lesser Antilles; revision of the historical seismicity. Bull Seismol Soc Am 78:1965-1983

Buckley ME, Wei Y, Jaffe, BE, Watt S (2010) Estimated velocities and inferred cause of overwash that emplaced inland fields of cobbles and boulders at Anegada, British Virgin Islands. Nat Hazards (this volume)

Caribbean Disaster Mitigation Project (2002) Atlas of probable storm effects in the Caribbean Sea. http://www.oas.org/CDMP/document/reglstrm/Hurratlas7D.ppt

Coch NK (1994) Geologic effects of hurricanes. Geomorphology 10:37-63

de Lange WP, de Lange PJ, Moon VG (2006) Boulder transport by waterspouts: an example from Aorangi Island, New Zealand. Mar Geol 230:115-125

Dix GR (1999) Marine saline ponds as sedimentary archives of late Holocene climate and sea-level variation along a carbonate platform margin; Lee Stocking Island, Bahamas. Palaeogeogr Palaeoclimatol Palaeoecol 150:223-246 
Donnelly JP (2005) Evidence of past intense tropical cyclones from backbarrier salt pond sediments: a case study from Isla de Culebrita, Puerto Rico, USA. Journal of Coastal Research SI 42:201-210

Dookhan I (1975) A history of the British Virgin Islands, 1672 to 1975. Caribbean Universities Press in association with Bowker Pub. Co, Epping, England

Dorel J (1981) Seismicity and seismic gap in the Lesser Antilles Arc and earthquake hazard in Guadeloupe. Geophys J Roy Astron Soc 67:679-695

Druffel ERM, Robinson LF, Griffin S, Halley RB, Southon JR, Adkins JF (2008) Low reservoir ages for the surface ocean from mid-Holocene Florida corals. Paleoceanography 23. doi:10.1029/2007PA001527

Dunn GE (1961) The hurricane season of 1960. Mon Weather Rev 89:99-108

Dunne RP, Brown BE (1979) Some aspects of the ecology of reefs surrounding Anegada, British Virgin Islands. Atoll Research Bulletin 236. The Smithsonian Institution, Washington, DC

Gardner TA, Côté IM, Gill JA, Grant A, Watkinson AR (2003) Long-term region-wide declines in Caribbean corals. Science 301:958-960. doi:10.1126/science.1086050

Geist EL, Parsons T (2009) Assessment of source probabilities for potential tsunamis affecting the U.S. Atlantic coast. Mar Geol 264:98-108. doi:10.1016/j.margeo.2008.08.005

Grindlay NR, Mann P, Dolan JF, van Gestel J (2005) Neotectonics and subsidence of the northern Puerto Rico-Virgin Islands margin in response to the oblique subduction of high-standing ridges. Geol Soc Am Spec Pap 385:31-60

Horsfield WT (1975) Quaternary vertical movements in the Greater Antilles. Geol Soc Am Bull 86:933-938

Howard J (1970) Reconnaissance geology of Anegada Island. Caribbean Research Institute, St. Thomas

Hughen KA, Baillie MGL, Bard E, Beck JW, Bertrand CJH, Blackwell PG, Buck CE, Burr GS, Cutler KB, Damon PE, Edwards RL, Fairbanks RG, Friedrich M, Guilderson TP, Kromer B, McCormac G, Manning S, Ramsey CB, Reimer PJ, Reimer RW, Remmele S, Southon JR, Stuiver M, Talamo S, Taylor FW, van der Plicht J, Weyhenmeyer CE (2004) Marine04 marine radiocarbon age calibration, 0-26 cal kyr BP; IntCal04; calibration. Radiocarbon 46:1059-1086

Jarecki LL (2003) Salt ponds of the British Virgin Islands: investigations in an unexplored ecosystem. Dissertation, University of Kent at Canterbury

Jarecki L, Walkey M (2006) Variable hydrology and salinity of salt ponds in the British Virgin Islands. Saline Systems 2. doi: 10.1186/1746-1448-2-2

Jarecki L, Burton-MacLeod SM, Garbary DJ (2006) Ecology of algal mats from hypersaline ponds in the British Virgin Islands. Algae 21:235-243

Kilbourne KH, Quinn TM, Guilderson TP, Webb RS, Taylor FW (2007) Decadal- to interannual-scale source water variations in the Caribbean Sea recorded by Puerto Rican coral radiocarbon. Clim Dyn 29:51-62. doi:10.1007/s00382-007-0224-2

LaForge RC, McCann WR (2005) A seismic source model for Puerto Rico, for use in probabilistic ground motion hazard analyses. Geol Soc Am Spec Pap 385:223-248

Lefèvre J (2009) High swell warnings in the Caribbean Islands during March 2008. Nat Hazards 49:361-370. doi:10.1007/s11069-008-9323-6

López AM (2006) Is there a northern Lesser Antilles forearc block? Geophys Res Lett 33 . doi: 10.1029/2005GL025293

Mackenzie FT (1965) Homotrema rubrum (Lamarck), a sediment transport indicator. J Sediment Petrol 35:265-272

Manaker DM (2008) Interseismic plate coupling and strain partitioning in the northeastern Caribbean. Geophys J Int 174:889-903

Mann P (ed) (2005) Active tectonics and seismic hazards of Puerto Rico, the Virgin Islands and offshore areas. Geological Society of America, Boulder, p 299

Mann ME, Woodruff JD, Donnelly JP, Zhang Z (2009) Atlantic hurricanes and climate over the past 1,500 years. Nature 460:880-883

McCaffrey R (2008) Global frequency of magnitude 9 earthquakes. Geology 36:263-266. doi: 10.1130/G24402A.1

McCann WR (1984) Subduction of aseismic ridges beneath the Caribbean Plate; implications for the tectonics and seismic potential of the northeastern Caribbean. J Geophys Res 89:4493-4519

McCann WR (1985) On the earthquake hazards of Puerto Rico and the Virgin Islands. Bull Seismol Soc Am 75:251-262

McCann W, Feldman L, McCann M (undated) Catalog of felt earthquakes for Puerto Rico and neighboring islands 1492-1899 with additional information for some 20th century earthquakes. Unpublished material provided as a pdf file by WR McCann, $122 \mathrm{pp}$

McCaul EW (1987) Observations of the Hurricane "Danny" tornado outbreak of 16 August 1985. Mon Weather Rev 115:1206-1223 
McCaul EW, Buechler DE, Goodman SJ, Cammarata M (2004) Doppler radar and lightning network observations of a severe outbreak of tropical cyclone tornadoes. Mon Weather Rev 132:1747-1763

Mercado-Irizarry A, Liu PLF (eds) (2006) Caribbean tsunami hazard. World Scientific, Hackensack, NJ

Millás JC, Pardue L (1968) Hurricanes of the Caribbean and adjacent regions, 1492-1800. Academy of the Arts and Sciences of the Americas, Miami

Morton RA, Sallenger AH Jr (2003) Morphological impacts of extreme storms on sandy beaches and barriers. J Coast Res 19:560-573

Muir-Wood R, Mignan A (2009) A phenomenological reconstruction of the Mw9 November 1st 1755 Lisbon earthquake. In: Mendes-Victor LA, Oliveira CS, Azebedo J, Ribeiro A (eds) The 1755 Lisbon earthquake, revisited. Springer, Dordrecht, pp 121-146

Novlan DJ, Gray WM (1974) Hurricane-spawned tornadoes. Mon Weather Rev 102:476-488

O'Loughlin KF, Lander JF (2003) Caribbean tsunamis; a 500 year history from 1498-1998. Kluwer Academic, Dordrecht

Pickering VW (1983) Early history of the British Virgin Islands: from Columbus to emancipation. Falcon Publications International, UK

Pilarczyk J, Reinhardt EG (2010) Homotrema rubrum (Lamarck) taphonomy as an overwash indicator in marine ponds on Anegada, British Virgin Islands. Nat Hazards (this volume)

Prospero JM, Lamb PJ (2003) African droughts and dust transport to the Caribbean: climate change implications. Science 302:1024-1027

Reid HF, Taber S (1920) The Virgin Islands earthquakes of 1867-1868. Bull Seismol Soc Am 10:9-30

Reimer PJ, Reimer RW (2001) A marine reservoir correction database and on-line interface. Radiocarbon 43:461-463

Reimer PJ, Baillie MGL, Bard E, Bayliss A, Beck JW, Bertrand CJH, Blackwell PG, Buck CE, Burr GS, Cutler KB, Damon PE, Edwards RL, Fairbanks RG, Friedrich M, Guilderson TP, Hogg AG, Hughen KA, Kromer B, McCormac G, Manning S, Ramsey CB, Reimer RW, Remmele S, Southon JR, Stuiver M, Talamo S, Taylor FW, van der Plicht J, Weyhenmeyer CE (2004) IntCal04 terrestrial radiocarbon age calibration, 0-26 cal kyr BP; IntCal04; calibration. Radiocarbon 46:1029-1058

Reinhardt EG, Pilarczyk J, Brown A (2010) Taphonomic and petrographic origins of a shell and sand sheet from marine ponds on Anegada, British Virgin Islands. Nat Hazards (this volume)

Robson GR (1964) An earthquake catalog for the eastern Caribbean, 1530-1960. Bull Seismol Soc Am $54: 785-832$

Schomburgk RH (1832) Remarks on Anegada. J R Geogr Soc Lond 2:152-170

Shepherd JB, Lynch LL (1992) An earthquake catalogue for the Caribbean; Part I, the pre-instrumental period 1502-1900. In: Report of the second technical workshop, seismic hazard project, Latin America and the Caribbean, Melbourne, Florida, pp 95-158

Stein S (1982) Subduction seismicity and tectonics in the Lesser Antilles Arc. J Geophys Res 87:8642-8664 ten Brink U (2005) Vertical motions of the Puerto Rico Trench and Puerto Rico and their cause. J Geophys Res 110. doi:10.1029/2004JB003459

ten Brink U (2009) Tsunami hazard along the U.S. Atlantic coast. Mar Geol 264:1-3. doi: 10.1016/j.margeo.2009.03.011

ten Brink U, Dillon W, Frankel A, Mueller C, Rodriguez RW (1999) Seismic and tsunami hazard in Puerto Rico and the Virgin Islands. U.S. Geological Survey Open-File Report 99-353. http://pubs. usgs.gov/of/1999/of99-353/

ten Brink US, Danforth WW, Polloni CF, Andrews B, Llanes P, Smith S, Parker E, Uozumi T (2004) New seafloor map of the Puerto Rico trench helps assess earthquake and tsunami hazards. EOS Trans Am Geophys Union 85:349

Toscano MA, Macintyre IG (2003) Corrected western Atlantic sea-level curve for the last 11,000 Â years based on calibrated $14 \mathrm{C}$ dates from Acropora palmata framework and intertidal mangrove peat. Coral Reefs 22:257-270

Watt S, Buckley ME, Jaffe BE (2010) Inland fields of dispersed cobbles and boulders as evidence for a tsunami on Anegada. Nat Hazards (this volume)

Woodruff JD, Donnelly JP, Emanuel K, Lane P (2008a) Assessing sedimentary records of paleohurricane activity using modeled hurricane climatology. Geochem Geophy Geosyst 9. doi:10.1029/2008GC002043

Woodruff JD, Donnelly JP, Mohrig D, Geyer WR (2008b) Reconstructing relative flooding intensities responsible for hurricane-induced deposits from Laguna Playa Grande, Vieques, Puerto Rico. Geology 36:391-394. doi:10.1130/G24731A.1

Zahibo N (2003) The 1867 Virgin Island tsunami; observations and modeling. Oceanol Acta 26:609-621

Zitellini N, Gracia E, Matias L, Terrinha P, Abreu MA, DeAlteriis G, Henriet JP, Danobeitia JJ, Masson DG, Mulder T, Ramella R, Somoza L, Diez S (2009) The quest for the Africa-Eurasia plate boundary west of the Strait of Gibraltar. Earth Planet Sci Lett 280:13-50 